\title{
Factors Contributing to IT Industry Success In Developing Countries: The Case of Thailand
}

\author{
Felix B Tan \\ School of Computer and Information Sciences \\ Auckland University of Technology \\ New Zealand \\ Email: felix.tan@aut.ac.nz \\ Kallaya Leewongcharoen \\ Department of Skill Development \\ Ministry of Labour \\ The Government of Thailand \\ Email:meja@rocketmail.com
}

\begin{abstract}
A stream of research exists that explores a country's information technology (IT) industry success. The theoretical model used in these studies is primarily focused on small-developed countries. We contend that the factors that contribute to IT industry success in developing countries are likely to differ somewhat to those that play a role in small-developed countries. Research to date on IT industry success has neglected developing countries. This study therefore presents an alternative IT industry success model for developing countries. It adapts Ein-dor, Myers and Raman's (1997) model in developing such a conceptual model. The adapted framework is then applied in a study of IT industry in a developing country - Thailand. We found IT-related foreign direct investment to be vital to IT industry success in Thailand. Unlike findings from earlier studies on small-developed countries, geographical location and to a lesser extent government investment promotion policies are also important to IT industry success in a developing country. These findings support the view that there are differences in the factors that affect IT industry success in developed and developing countries. Implications for research and practice are discussed.
\end{abstract}

KEYWORDS: IT industry success; developing countries, Thailand, foreign direct investment, geographical location, government policies

\section{INTRODUCTION}

Information Technology (IT) affects our everyday lives at both an individual and organizational level. It is clear that we cannot avoid the use of technologies, and it is important that we know how to live with those technologies fittingly. At a country level, many countries accept the importance of IT and intend to utilize IT to improve the quality of life of their citizens and to facilitate economic growth. It is widely accepted that the effective use of technology can 
bring successful industrial growth [42]. Therefore, the adaptability of countries to the change from an Industrial Technology era to an Information Technology era becomes crucial. Consequently, the study of IT industry success in countries is important as it helps countries become aware of their level of IT industry success and provides guidelines for policy makers to further plan their countries’ development.

Such a stream of research exists. For example, Ein-dor, Myers and Raman [22] described and studied the IT industries in Israel, Singapore and New Zealand. The authors developed and tested a model describing the factors affecting IT industry success. In another study, Finland and New Zealand were examined [75]. These studies conclude that government policy in promoting IT production/use, as well as the level of research \& development, and the existence of an education system that produces IT literate graduates are key factors that contribute to IT industry success in these countries.

However, the theoretical model used in these studies is primarily focused on small-developed countries. For instance, Ein-dor, Myers and Raman's conceptual framework was grounded in the work of Grossman and Helpman [25], with a focus on small-developed countries - New Zealand, Israel and Singapore. Watson and Myers [75] adapted this model with a focus on small-developed countries - Finland and New Zealand.

The ability to produce and use computer technology related products are emphasized in many developed countries. However, the challenge of building a country's IT industry is not faced by developed countries alone, but also by developing countries, as their trading partners are often from information-rich countries. As Talero and Gaudette [66] stated, “[d]eveloping countries must also adjust or suffer exclusion from the global economy and severe disadvantage in the competitiveness of their goods and services. They are threatened with a new and dangerous form of information poverty that could further widen the gap in economic status and competitiveness” [p.18]. This study therefore extends this stream of research by advancing our understanding of IT industry success in the context of developing countries.

We contend that the factors that contribute to IT industry success in developing countries are likely to differ somewhat to those that play a role in small-developed countries. For instance, developing countries face inadequate sustainable sources of funding [18] and are likely unable to fund the level of research and development required for IT industry success as identified by the earlier studies. At the same time, many developing countries depend highly on foreigndirect investments to sustain economic growth [47] and as such we can expect such investments to have a strong impact on success of IT in these countries.

This study therefore presents an alternative IT industry success model for developing countries. It adapts Ein-dor, Myers and Raman's [22] model in developing such a conceptual framework. Using the adapted framework, this study investigates IT industry success in a developing country - Thailand. Thailand was chosen as the subject of this study due to the country being in a position that is highly challenged by the changes required in the Information Technology era. Thailand has been performing well in economic growth during the Industrial Technology era. The country is one 
of only three developing countries that are counted among eight "High-Performing Asian Economies” [78]. The rapid growth of Thailand was underpinned by Foreign Investment encouraged by cheap labor costs [32, 34]. However, as its economy is expanding, increasing labor costs can be expected. Thailand will no longer have a comparative advantage in low-wage labor and, thus, will lose this advantage to new comers such as China and Vietnam [34, 47]. Thailand needs to seek other competitive advantages. To some extent, it needs to be able to adopt and employ technology in order to confront the changing environment. A similar situation has previously been faced by Singapore. The success of the IT industry in Singapore was attributed to its ability to improve the level of technology according to the rising wages and the challenge from the new comer, lower-waged countries [19]. An ability to shift from the Industrial Technology era, utilizing an abundance of low-wage labor, to the Information Technology era, relying on more educated workers with skills in IT, is a challenge facing developing countries like Thailand.

This study contributes to both research and practice. It extends existing knowledge of IT industry success, which is currently limited to small-developed countries, by presenting an alternative IT industry success model for developing countries. The model assumes that developing countries face somewhat different challenges in order to develop their own IT industry. In practice, this research is expected to help developing countries to assess their level of IT industry development compared with competing countries in order to achieve long-term economic growth. Specifically, this study will highlight factors that impact the IT industry in Thailand. This will help policy makers as well as IT industry stakeholders in the nation to focus in the right direction in order to develop their nation's IT industry.

This paper begins by discussing the literature on IT industry success, in particular Ein-dor et al's [22] model and related studies. We then introduce our model of factors affecting IT industry success in developing countries. In this section, we present how we adapted Ein-dor et al's model - the factors we retained and additional factors that we consider pertinent to IT industry success in developing countries. The research methodology then follows. We then provide some background to Thailand and the country's IT development history. The results and discussion are then presented. Finally, the conclusion follows.

\section{PRIOR RESEARCH ON IT INDUSTRY SUCCESS}

IT industry in this study is defined as all industries that fall into a range of upstream to downstream of IT industry value chain. The upstream industries in the IT industry value chain are those industries producing hardware components such as manufacture of semi-conductors, while the downstream industries are more intangible industries, such as services and support, but closer to end users. Industries in between upstream and downstream industries are those involving telecommunication, data management and software.

Ein-dor et al [22] developed a framework that focuses mainly on small-developed countries and IT industry success is measured by the value of IT sales and IT exports. The model, presented in Figure 1, is largely based on the macroeconomic model of Grossman and Helpman [25]. 


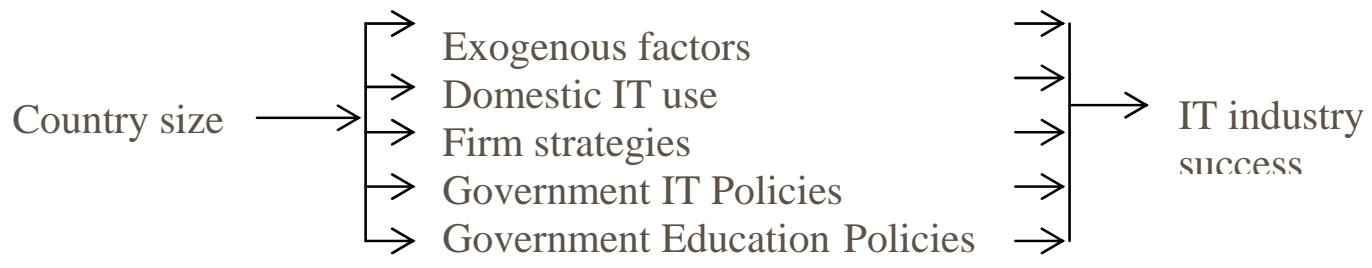

Figure 1: Ein-dor, Myers and Rahman's Model of Factors Affecting IT Industry Success [22]

Factors in this model are categorized into control variables, dependent variable, and exogenous and endogenous mediating factors. Control variables determine the countries to be included in the study - eg. country size [22]. IT industry success is a dependent variable in this model. It determines the degree to which the country is successful in the IT industry. The exogenous mediating factors are those factors that we have less or no control over and normally are accepted as given (eg. geographical location), while more control and influence can be placed on endogenous mediating factors through firms or government (eg. firm strategies and government IT policies) [22]. This model was used to assess the IT industry in three small-developed countries, which are Israel, Singapore and New Zealand. The research found that the dominant factor that seems to influence success of IT industries is government policies in promoting IT industries, supporting R\&D and in providing appropriate, trained labor.

In 2001, Watson and Myers [75] developed a similar framework for studying IT industry success in small-developed countries by adapting the existing model of Ein-dor et al [22]. The only difference between these two models is that instead of firm strategies, level of R\&D is introduced to the model, portrayed in Figure 2. The authors argue that level of R\&D provides a better explanation to the model.

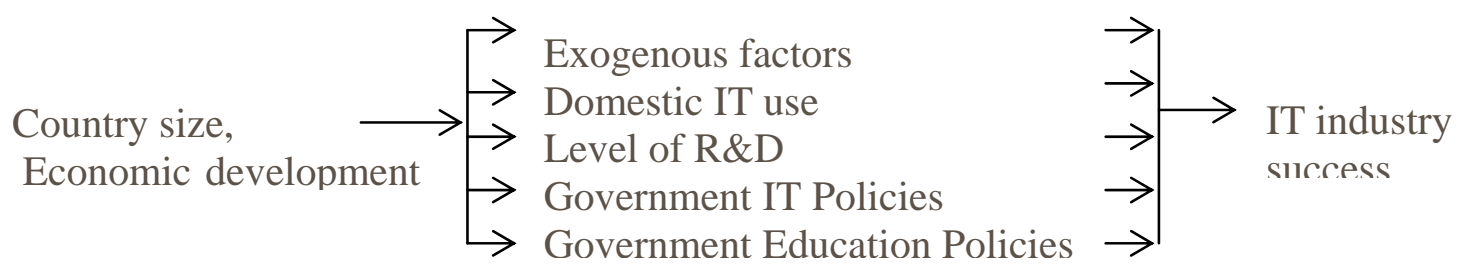

Figure 2: Watson and Myers' Model of Factors Affecting IT Industry Success (adapted from Ein-dor et al. [22])

This adapted model was used to compare success of IT industries in Finland and New Zealand. The results of the study show that high levels of investment in R\&D, especially in the private sector, have contributed to success of the IT industry. Moreover, the other major factors influencing IT industry success found in the study are government IT promotion and education system, which produce IT human resources. 


\section{A FRAMEWORK FOR IT INDUSTRY SUCCESS IN DEVELOPING COUNTRIES}

Similarly, this study has adapted Ein-dor et al's original model [22]. However, the purpose of developing the model is to explain IT industry success in developing countries rather than small developed countries. The model employs a similar rationale as the previous model - that country size and economic development impact on IT industry success through exogenous and endogenous mediating factors. This study further includes political stability as a control variable. The rationale of including this control variable is discussed later in the paper. Moreover, in this study, the five mediating factors are, in part, believed to influence the level of IT-related Foreign Direct Investment (FDI) into the host country. In other words, these mediating factors are expected to have both direct and indirect (through ITrelated FDI) effects on IT industry success in developing countries. We assume that these factors, together with ITrelated FDI, will explain IT industry success in developing countries. The model is presented in Figure 3.

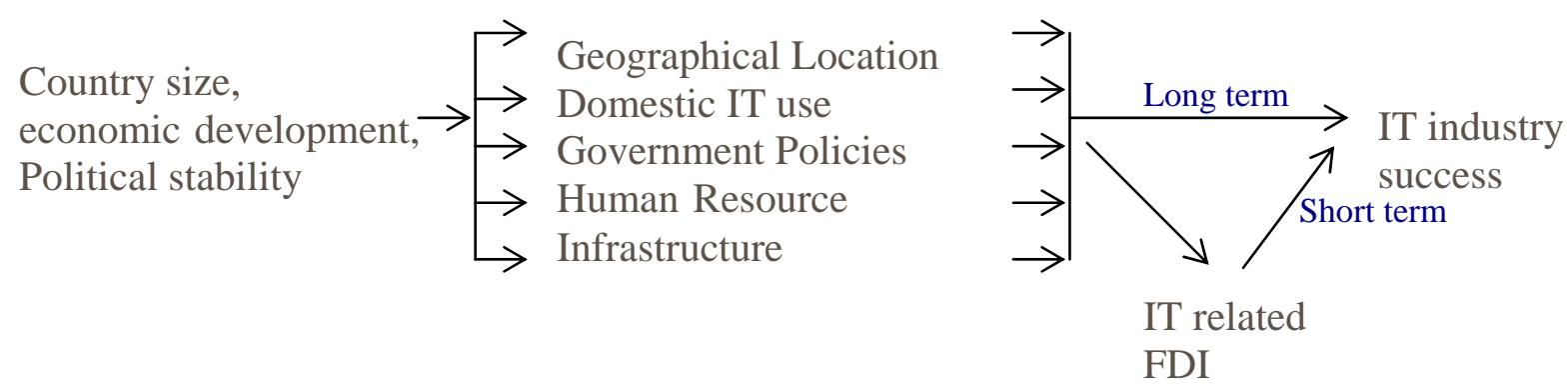

Figure 3: Model of Factors Affecting IT Industry Success in Developing Countries (adapted from Ein-dor et al. [22])

A number of changes have been made to the original model [22] and the adapted model [75]. Firstly, firm strategy factor is excluded from the model. This factor has been found not to contribute to IT industries developments in prior research [22]. Different types of companies in different countries may have different strategies. Therefore, it is hard to measure whether one is superior to the others. Consequently, it is difficult to conclude whether the factor influences the success of IT industry. Secondly, the level of R\&D is considered part of government policies. We expect that developing countries have considerably less funding on R\&D than those developed economies [18]. Thirdly, the government education policy factor became part of, the newly introduced, Human Resource factor in order to emphasize the importance of human capital as an input to IT industry growth. Fourthly, technology infrastructure, which used to be part of domestic IT use, is one of the factors in the model and it is assumed to be significant to the development of the IT industry. Lastly, investment from an IT related foreign company is included as one of the factors in this new model.

In the following section, we present rationales for including the factors in the model. 


\section{a. Control Variables}

On a broad level, we consider three factors - country size, level of economic development and political stability, as control variables.

\section{Country size}

Large countries, such as the United State and Japan, seem to be advantaged in many ways, especially in the world economy. However, Dedrick et al [19] have found that small size, either geographically or demographically, can also be an advantage in IT development. For instance, government can fulfill demands of infrastructure easier. Previous research on IT industry success in small developed countries have also shown that small country size does not disadvantage the development of IT [22, 75]. Even though this study examined a single country, this control variable has been retained for the purpose of assessing IT industry success in developing countries in future studies employing the current model.

\section{Economic Development}

Previous research has shown that economic development has a close relationship with a country's IT production. For instance, Kraemer, Gurbaxani and King [42] state that demand for IT production is largely determined by the level of economic development. Kraemer and Dedrick [38] argue that this is not exactly true when the country focuses on foreign markets more than domestic markets. However, they also pointed out that the level of economic development could also influence the quality of infrastructure, which supports the growth and use of IT. In this study, we consider economic development has a relationship with IT industry in developing countries. It implies the ability of a country to provide the necessary environment for development of the industry and the ability of the population to embrace IT. Even though this study examined a single country, we include this as one of control factors to filter only developing countries for consideration. This factor should remain in future comparison studies, to ensure that IT industry success is not affected by a confounding effect related to differing levels of economic development.

\section{Political Stability}

According to Katz [35], the transition to an Information Society in developed countries can be described by variables in economics; on the contrary, in developing countries, politics is the decisive variable influencing the transition to an Information Society. Furthermore, political stability influences the private sector's decisions whether to invest in a high risk industry like IT in a particular country [38]. Political environment was considered as part of the environment factors that influence Technology policies and IT production in Kraemer and Dedrick's [38] study. In our study, we consider that political stability may impact IT development in developing countries. As a result, Thailand was selected for study because of its political stability. 


\section{b. Dependent Variable}

Ein-dor et al [22] employed, mainly, the level of IT sales and IT exports as indicators to determine IT industry success, while Kraemer and Dedrick [38] focused more on the breadth and depth of IT production and production levels. Both were able to justify their choices. The research on IT industry in small developed countries has tried to prove that IT products produced by a certain country are internationally accepted; therefore the level of IT exports is an important factor in determining success. On the other hand, Kraemer and Dedrick [38] have tried to present the sophistication of IT production in the studied countries; therefore breadth and depth of IT production, and production level are considered as dependent variables. In the present study, Thailand has a demonstrably high level of exports and we have considered it sufficient to consider the level of IT sales and production and IT export as keys to determine IT success.

\section{c. Mediating Factors}

\section{Geographical Location}

Even though the previous works on IT industry success in small developed countries [22, 75] have concluded that location is not associated with the success of IT industry, Dedrick et al [19] have found that those countries that succeed in hardware industry are those that have advantageous geographic locations. Moreover, Watson and Myers [75] suggested that geographical location may have a slight impact on the hardware sector. Therefore, location related factors should not be underestimated but considered as one of the factor that may contribute to IT industry success in developing countries, especially the hardware sector.

\section{Domestic IT Use}

Domestic IT use is an important factor, as it represents the extent to which the population and organizations use technology within the country. The degree of use of IT in a country reflects how comfortable the population is with technology. Heavy use implies high demand for IT products from the domestic market. The larger the demand is, the more likely investment in the industry will be, and therefore the more likely the industry's success is. Moreover, Eindor et al [22] indicated that the intensive domestic use of IT has been considered to be important to the indigenous IT industry. However, if a country focuses on external markets, domestic use of IT may not be that important to its IT industry success. In addition, according to Kraemer and Dedrick [38], the level of economic development largely impacts on the domestic use of IT. Therefore, this factor can be expected to have less significance for IT industry success in developing countries, which generally have lower levels of economic development than developed countries. Nonetheless, this factor is included in the theoretical model of this study to test whether there is empirical support.

\section{Government Policies}

Diffusion of IT in developing countries has been found to be more influenced by government than in developed countries [35]. Similarly, the development of IT industries in developing countries may be largely influenced by 
government policies. In order to facilitate a country's IT industry success, government can stimulate the industry in several ways. Indirectly, it can stimulate the use of information technology in the private-sector through taxes, tariffs, training and subsidies. It can also directly stimulate the IT industry through spending [42]. Even though Kraemer et al. [42] concluded that government policy toward computing did not relate to economic development and investment in computing technology, Ein-dor et al [22] found that there was a relationship between government policies and domestic IT production. Therefore, in this study, government policy is included as one factor that may contribute to IT industry success in developing countries. A scheme to analyze government policies is adopted from Kraemer and Dedrick's [38] study. They categorized government policy relating to the IT industry into three categories: macroeconomic and industrial policies; external policies; and internal policies. Macroeconomic and industrial policies were not considered in the research as they were considered to be less relevant to IT production than the other two [38]. External policies relate to the international environment; such as trade, foreign investment and technology transfer policy [38]. This includes incentives for and regulations on the IT industry. Internal policies are those policies that more directly relate to the IT industry, such as supporting the domestic IT industry, increasing domestic demand and investment in infrastructure [38]. Therefore, in this study, sub-variables that we consider within government policies are: government IT, trade, and investment promotion policies. Moreover, the level of support for R\&D that Ein-dor et al [22] and Watson and Myers [75] found to influence IT development is also included as a measure of government policy support for the IT industry.

\section{Human Resources}

Human resources are an important input for most industries, including the IT industry, and especially the software sector, where human creativity is considered crucial. Human resources are considered the key asset for the software sector [27]. The ability of workers to use English, which is the language used for programming, and the ratio of scientists and engineers to general population have been found to be positively related to the level of software exports [38]. In the hardware sector, even though human resources are not as crucial as for the software sector, human resources required range from semi-skilled labor to scientists and engineers. Both Ein-dor et al [22] and Watson and Myers [75] found that government education policies that produced well educated workers contribute to IT industry success. This means that well educated workers are significant to IT industry success in developed countries. In this study, we consider whether either workers who might be considered skilled labor or well educated workers like IT professionals, scientists and engineers are a significant factor in IT industry success in developing countries.

Moreover, the availability of IT professionals and skilled labor can encourage foreign investors to set up high technology manufacturing within a country. Singapore, for example, has been successful in persuading MNCs to locate advanced manufacturing facilities within the country by training IT professionals as a part of national policy [19]. 


\section{Infrastructure}

Physical infrastructure is closely related to a country's level of economic development, including both IT industry production and industry investment. According to Kraemer and Dedrick [38], the number of telephones per capita has shown a significant correlation with software production, as telephone lines act as communication channels for the data transmission necessary for software development. An efficient telecommunication infrastructure is beneficial to both the use and production of IT [19]. Moreover, a case in Singapore studied by Kraemer and Dedrick [40] has shown that the availability of efficient infrastructure is a factor that attracts private companies to invest in a country. By contrast, a lack of infrastructure can discourage the private sector from taking a risk in investment in an industry. To be able to achieve a successful IT industry, countries should, therefore, have a reasonably developed and available infrastructure to support the industry. However, unlike developed countries, developing countries face the problem of inadequate infrastructure. For instance, although developing countries have been trying hard to invest in infrastructure and doubled their share of world telephone lines from 7 to 12 percent between 1969 to 1988 [66], the gap between industrial and developing countries remains large compared with their population [66]. The lack of a infrastructure can discourage private sectors to take risks in their investments [38]. It also can lead to the problem known as 'digital divide' [79]. Consequently, the number of population with computer literacy is limited.

Therefore, infrastructure is expected to have some influence on development of IT industry. In this study, infrastructure focuses mainly on telecommunication infrastructure and internet access. It refers to the required infrastructure that facilitates and supports growth of the IT industry. Technology infrastructure may be investment made by government or private sector. However, in developing countries, the government is expected to be the main player investing in fundamental infrastructure.

\section{IT related Foreign Direct Investment}

Generally, developing countries lack resources, such as industry technological resources, IT human resources and capital, which facilitate growth in IT. Inflows from foreign firms can provide these fundamental elements to developing countries. There are two forms of foreign private capital flows, equity and debt, of which Foreign Direct Investment (FDI) is the largest type of equity flow into developing countries [55].

FDI is defined as "investment in which a firm acquires a substantial controlling interest in a foreign firm (above 10 percent share) or sets up a subsidiary in a foreign country” [13]. For developing countries, FDI seems to be a necessary factor for the hardware sector, which requires substantial amounts of capital, technological resources and expertise in technology [46]. Jomo [32] pointed out that developing countries can gain benefits from FDI, not only by compensating for their human resource inadequacies, but also by influencing FDI to maximize gains in terms of technology transfer and higher incomes through host government intervention. In addition, multinational corporations, which are one source of FDI, are important links that can integrate a country's production of IT hardware into the global production chains [19]. Clearly, without FDI, it seems to be difficult for developing countries to compete as a world class IT manufacturer. 
The present research is a study of Thailand, which is one of the Asian developing countries that UNCTAD [cited in 55] declares to have gained as much as 12 percent of the total global FDI inflows. The share of FDI to developing countries has been increasing, from less than 25 percent of global FDI flows in 1991 to 42 percent in 1998 [55]. This increasing trend of investment in developing countries is a good sign for developing countries looking for FDI as a source of IT industry development.

\section{RESEARCH METHODOLOGY}

\section{Data Collection and Data Sources}

The research methodology involved collecting secondary data. This approach is consistent with previous studies on IT industry success [22, 75]. The unit of analysis was Thailand's IT industry. Thailand is one of a number of developing countries that has high exports of IT products. This study adopted Ein-dor et al's [22] main criteria for indicating IT industry success - the production and the export of IT products. Prior to the process of data collection, operationalization of concepts into measurable groups of elements was established, based on previous research [22]. This served to reduce the abstraction of concepts of the research. This operationalization defines necessary data for analysis and is presented in Table 1.

\begin{tabular}{|c|c|c|}
\hline Variable groups & Variables & Operationalizations \\
\hline \multirow[t]{3}{*}{ 1. Controlled variables } & Country size & $\begin{array}{l}\text { Population } \\
\text { Area }\end{array}$ \\
\hline & General economic development & GDP per capita \\
\hline & Political stability & Political stability \\
\hline \multirow[t]{2}{*}{ 2. Dependent variables } & IT production development & $\begin{array}{l}\text { IT product sales \& contribution to } \\
\text { GDP }\end{array}$ \\
\hline & IT industry success measures & $\begin{array}{l}\text { Locally developed IT products } \\
\text { IT industry exports } \\
\text { Stock market listings }\end{array}$ \\
\hline $\begin{array}{l}\text { 3.Exogenous mediating } \\
\text { factors }\end{array}$ & Geographical location & IT market proximity \\
\hline \multirow[t]{2}{*}{$\begin{array}{l}\text { 4.Endogenous mediating } \\
\text { factors }\end{array}$} & Domestic IT use & $\begin{array}{l}\text { IT spending relative to GDP } \\
\text { Number of computers installed Use } \\
\text { of telecommunications } \\
\text { Use of Internet }\end{array}$ \\
\hline & Government IT policies & $\begin{array}{l}\text { Priority of IT development } \\
\text { Level of R\&D support } \\
\text { Investment promotion policy } \\
\text { Tax incentives } \\
\text { Trade policy }\end{array}$ \\
\hline
\end{tabular}




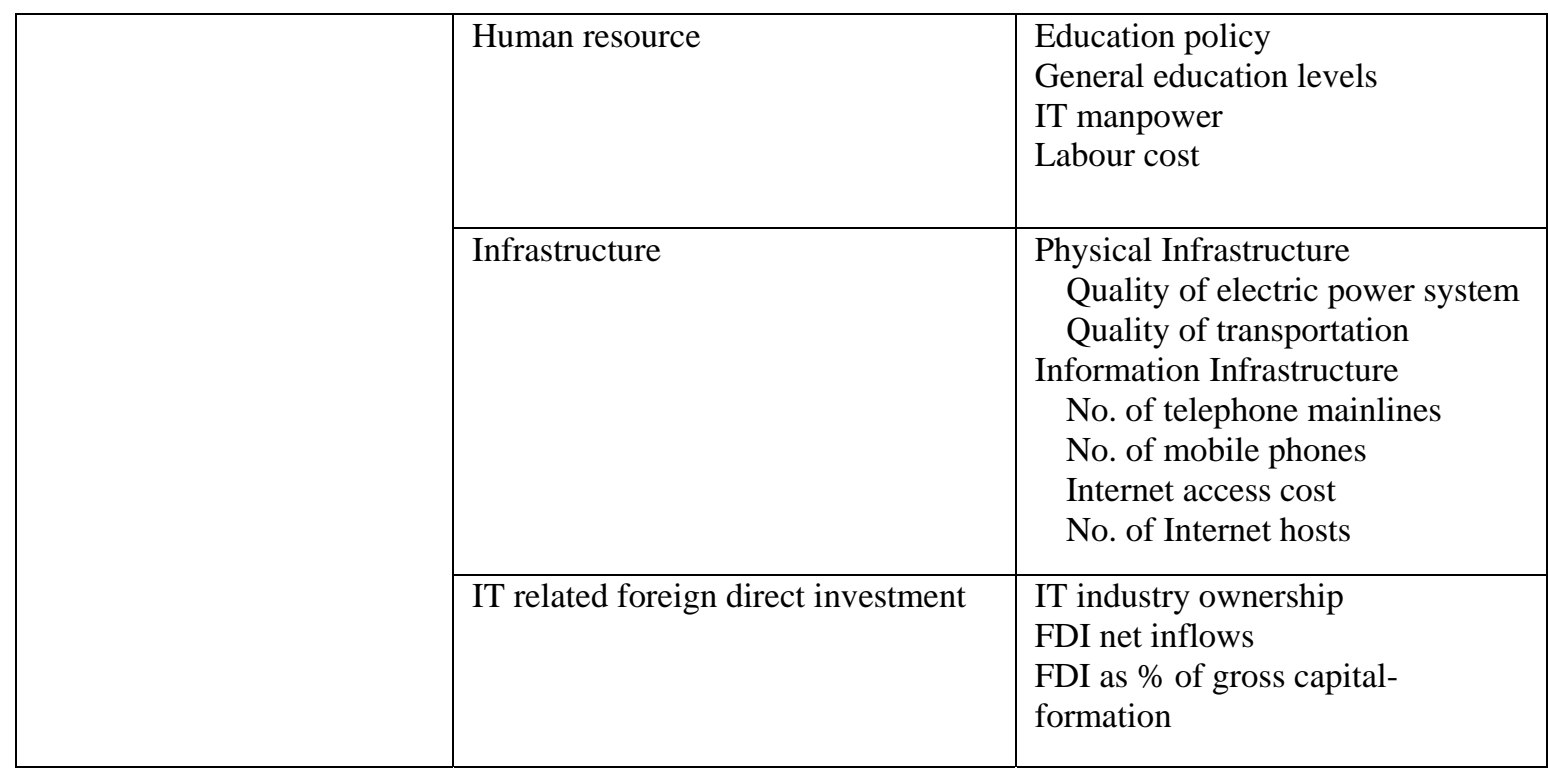

Table 1: Operationalization of Variables (adapted from Ein-dor et al [22])

From this table, "table shells" were created to represent the array of data that needed to be collected for each variable. Data collection consisted of locating data to fill the "table shells".

Multiple sources of data used in this study, including, (i) published journal articles and books such as World Electronics data and World Development Indicators; (ii) newspapers; (iii) research conducted by independent research institutes such as the Centre for Research on Information Technology and Organizations (CRITO); (iv) research conducted by Thai universities eg. Thammasat University; (iv) government organizations such as Software Park Thailand, National Electronics and Computer Technology Centre, Association of Thai Computer Industry (ATCI), Board of Investment Thailand (BOI); (v) research and reports from Internet web sites; (vi) an interview and subsequent correspondence with the General Secretary of ATCI, Thailand.

\section{Data Analysis}

Data reduction, data display, and conclusion drawing/verification were conducted as parts of analytic procedures suggested by Miles and Huberman [49]. The process of data reduction includes data selection, paraphrasing and summarization. Tables of category summaries were used for placing evidences into. Figures and tables were used for displaying data. Conclusion paragraphs were drawn based on presented evidence. The analytic strategy employed in this study was similar to Yin's [see 81] 'explanation-building' strategy. This strategy helped focus attention on data that provided evidences to analyze the relationships identified in Figure 3. The analysis was based on the presumption that Thailand had developed a successful IT industry as it fulfilled the key indicators of IT industry success 
established by Ein-dor et al [22]. Secondary data were then analyzed to establish whether there are evidences to support the relationships.

\section{RESULTS AND ANALYSIS}

\section{a. Thailand: The Country}

Thailand used to be known as 'Siam' until 1949 when it was officially proclaimed 'Thailand', which means the land of freedom. It is the only country in the region that has never been colonized by the English and French, unlike its neighbors Myanmar, Malaysia, Laos etc. Table 2 presents some statistics on Thailand's size and economic development.

\begin{tabular}{|l|l|}
\hline Country Size and Economic Development & Thailand \\
\hline Population (millions) & 61.2 (a) \\
\hline Population rank & $19 / 227$ (a) \\
\hline Surface Area (sq. km) & 513,115 (c) \\
\hline Population Density (persons/ sq. km) & 119.3 (a) \\
\hline Per-capita GNP (US\$) & 3390 \\
\hline GDP (million US\$) & 122,300 (c) \\
\hline Per-capita GDP (US\$) & 2,018 (c) \\
\hline Per-capita GDP Rank & $56 / 116$ (d) \\
\hline
\end{tabular}

Table 2: Country Size and Economic Development (adapted from Ein-dor et al [22]; Watson and Myers [75] ) Sources: World Development Indicators database, April 2002; Centre for Economic and Policy Research note : (a) = yr 2002, (b) = yr 2001, (c) = yr 2000, (d) = 1999, (e) = 1998, (f) =1997

Geography. Situated in the middle of Southeast Asia, Thailand covers an area of 513,115 square kilometres. The country contains mountains, tropical rainforest, and flat plains. In the north it is connected to Myanmar and Laos, in the east to Cambodia and the Gulf of Thailand, in the west to Myanmar and the Indian ocean, and in the south to Malaysia [3]. Thailand has two long coastlines, one, approximately 1,840 kilometres, on the Gulf of Thailand and the another, 865 kilometres long, on the Indian Ocean [3].

People. The population of Thailand is 61.2 million and the population density is 119.3 people per square kilometre. The annual population growth rate was 0.7 percent during 1995-2001 [76]. Ethnic groups comprise eighty percent of Thai, twelve percent of Chinese, four percent of Malaysian and three percent of Khmer. Buddhism is the major religion in Thailand; 95 percent of Thai are Buddhist, four percent are Muslim and one percent is Christian. Thai is the official language. English is a second language and is taught in public schools. 
Political Stability. Thailand is considered to have a relatively stable government. This can be seen from the country often being chosen to be the regional base for foreign companies [58]. Moreover, the stable political situation, strong social foundation and sound macro-economic policies are the factors that influence the impressive economic growth of the eight high performing east Asian countries, which include Thailand, proclaimed as the East Asia miracle [45].

Economic Development. Thailand has employed two main economic strategies - an import-substitution strategy and an export-orientation strategy. The former, employed during 1960-1972, aimed at producing commodities for the domestic market, while the latter, employed since 1972, focused on expanding the limited domestic market by export to external markets [1]. During the import substitution industrialization (ISI) strategy, Thailand faced a lack of entrepreneurs to carry out industrialization. As a result, many foreign investors were invited invest in Thailand and a large number of them cooperated with local enterprises in joint ventures with the incentive of lowering the tariff protection [1]. After continued ISI for ten years, the growth in some import-competing industries started to slow down due to the limited domestic market. Therefore, since 1972, Thailand has been embracing export oriented industrialization (EOI) and during the 1970s a number of products became significant to Thailand's exports, including textiles, clothing and electronics assembly [1]. During the second half of the 1980s, leather products, transport equipment, plastic products, electrical machinery, rubber products, apparel, textiles, furniture, paper products, chemical products and metallic products were the fastest growing manufactured exports [UNIDO cited in 1]. A large inflow of foreign direct investment from Japan and the newly industrialized countries (NICs) of East Asia was the source of a rapid expansion of the manufacturing sector and the high growth rate of the economy in the second half of the 1980s [1]. Thailand is claimed to be the 'Detroit of the East' as many automotive manufacturers, such as General Motors, Ford, Chrysler, BMW and Renault, chose to locate their regional production base in Thailand [2]. Thailand had been enjoying impressive economic growth rates; approaching ten percent before the down turn of its economy in 1997 [17]. The bubble-burst economy brought the devaluation of Thai baht (the local currency) and major disruption to Thailand's industry. Since the financial crisis, an FDI inflow of more than twelve thousand million US dollars into Thailand has been estimated, mainly in the form of mergers and acquisitions added to stabilise existing companies [2].

Trading partners. The major countries that Thailand imports products from are Japan, the United States, Singapore, Malaysia and Germany, while the major destinations for products exported from Thailand are the United States, Japan, Singapore, Hong Kong and Malaysia.

\section{b. Thailand's IT Development History}

\section{Hardware Industry}

The history of Thailand's IT industry began with the development of an electronics industry, which spans approximately four decades. The development during 1960-1995 can be divided into five phases [72]. 
The first phase was the development of the electronics industry under import-substitution policies (1960-1970). During this period, there were many Japanese investors and the industry was largely dominated by five Japanese joint ventures, namely SANYO, Matsushita, Mitsubishi, Toshiba and Hitachi [1, 72]. The second phase saw a shift from import substitution to an export oriented strategy (1971-1980). The government switched to export-oriented policy and provided many incentives; such as zero tariffs on materials inputs, machinery, and equipment [72]. These incentives, in addition to cheap labour costs in Thailand, attracted a number of American MNCs to invest in Thailand, especially in IC packaging for exports [1]. The huge production and export of ICs was the main driver of the industry's growth [72]. The third phase of export promotion occurred during 1981-1985. At first, the industry was producing electronics products locally, not merely assembling, and was again dominated by Japanese investors [72]. The value of investment in the industry during this period was higher than for the first two phases added together [72]. Since 1985, computers and computer parts have become the leading export industry of Thailand for the first time [16]. The fourth phase was the electronic industry during the 1986-1990 economic boom. During this period there was a dramatic increase in investment from Japan, Taiwan and other Asian NICs. As a result, the number of firms newly operated during the period became 368 [72]. There were many new products primarily produced for export; such as floppy disk drives, printers, computer parts and components, and including higher value-added products like facsimiles, satellite receivers, hard disks, modems and computers. The final phase was the supporting industry (1991-1995). There were 295 new firms, 283 of which aimed at supplying parts and components to world electronic manufacturers in Thailand [72]. Although still dominant, FDI became less significant than in the prior period due to many of the new firms being local [72].

Currently, it is estimated that approximately ninety percent of Thailand's electronics industry is dominated by multinational companies [23]. However, the long development of the electronics industry has paved the way for Thailand to become one of the major hardware exporting countries. The heavy investment from Japan and Southeast Asian NICs, such as South Korea and Taiwan together with strong support from government caused rapid growth in the electronics industry from the late 1980s until the early 1990s [26, 60].

\section{Software Industry}

Unlike the hardware industry, which has had a long period of development, the software industry in Thailand is still considered to be at an early stage of development. Approximately seventy percent of the software market is imported [62]. In 1997, Software Park Thailand was established under the National Science and Technology Development Agency (NSTDA) to be a national cluster for software industries. The four main roles of the organization are to: transfer technology to software companies; promote Thai software to the local and global market; support young software companies during their start-up period; and provide operational space and technical infrastructure for software companies. Currently, there are 43 software firms, utilizing all available space, in the Software Park building, with 14 firms being international joint ventures (Finland, Switzerland, Germany, the United States, Taiwan, Japan and Singapore). The software industry is considered a significant growth prospect because the country has an advantage in labor costs. 


\section{c. Dependent Variable - IT Industry Development and Success}

The export of manufactured products has been increasingly significant to overall exports; the proportion of manufactured exports has shifted from just over two-fifths in 1985 to approximately three-quarters in 1995 [60]. In addition, among manufactured products, the electronics industry has been the leading sector in the country's economic growth and industrialization for the past twenty years. Export of electronic products increased from less than 600 million US dollars in 1985 to 14,700 million US dollars in 1998 [60]. Of this amount, approximately 50 percent comprises computer products and parts. In this section, Thailand's IT industry success, lead by the success of hardware industry, is illustrated, based on criteria established by researchers in previous studies of IT industry success in small developed countries. These criteria are summarized in Table 3.

\begin{tabular}{|l|l|}
\hline IT Industry Success & Thailand \\
\hline IT industry development & $9,200(\mathrm{e})$ \\
\hline IT industry sales (US \$ million) & $11(\mathrm{e})$ \\
\hline IT industry as percentage of GDP & $3000(\mathrm{a})$ \\
\hline Number of Firms in IT & $13 / 200$ (a) \\
\hline IT firms/largest firms & 146,000 (a) \\
\hline IT industry employment & \multicolumn{2}{l|}{} \\
\hline IT industry success & $8,369(\mathrm{e})$ \\
\hline IT production: & $199.5(\mathrm{c})$ \\
\hline Hardware (US \$ millions) & \multicolumn{2}{|l|}{} \\
\hline Software (US \$ millions) & 8,263 (e) \\
\hline IT exports: & less than 12 (a) \\
\hline Hardware (US \$ millions) & 8,275 \\
\hline Software (US \$ millions) & $13,999(\mathrm{~d})$ \\
\hline Total & $32 \%$ (d) \\
\hline High Technology Exports (US \$ millions) & 31 \\
\hline High Technology Exports/Manufactured exports & 0 \\
\hline Stock market listing & \\
\hline Domestically listed IT firms & \\
\hline Internationally listed IT firms & \\
\hline
\end{tabular}

Table 3: IT Industry Success and Development (adapted from Ein-dor et al [22]; Watson and Myers [75])

Sources: World development report 2000/2001, US Department of Commerce: International Trade Administration, Yearbook of World Electronics Data, World Development Indicator 2001, The Stock Exchange Thailand, Ministry of Commerce: Department of Commercial Registration, General Secretary of Association of Thai Computer Industry.

Note: (a)= yr 2002, (b)= yr 2001, (c)= yr 2000, (d)= yr 1999, (e)= yr 1998, (f)= yr 1997 


\section{IT Industry Development}

In this study, IT industry development is measured by IT product sales, its contribution to GDP, the number of firms in IT and total employment within the industry.

IT Industry Sales: IT industry sales represents the total of domestic IT spending aggregated with IT exports. According to Table 3, in 1998 IT industry sales were 9,200 million US dollars, which accounted for 11 percent of GDP $[7,60]$. Of this, foreign and domestic markets accounted for approximately 90 and 10 percent respectively.

Number and Size of IT Firms: There are figures available for the number of IT-related companies registered with the Department of Commercial registration (Ministry of Commerce), but these figures do not cover all areas of the IT industry. According to this source in 2001, there were 1,390 companies engaged in the manufacturing of electronics, computer and telecommunication equipment, 890 companies in telecommunication services, and 1,296 companies in software development, data typing services and data processing by machine services. Supporting data are given by Mr. Jumrud Sawangsamud, General Secretary of Association of Thai Computer Industry, who estimated that there are approximately 3,000 IT firms in Thailand; they can be divided into large, medium and small size companies. There are around 100 to 200 large size companies with each employing more than 100 employees. There are about 400 medium size firms with about 50-100 employees per firm and there are approximately 2,500 small size firms with each employing less than fifty staff. IT industry employment, therefore, is estimated to exceed 146,000 persons. According to the BOI (2002b), employment in the computer and peripheral industry alone accounted for 26 percent of the total electronics industry, which was 78,000 persons.

\section{IT Industry Success}

IT industry success is measured by the ability to produce and export both IT products and high technology products. The level of IT exports reflects the extent to which world markets accept local IT products. Moreover, the number of local companies that are able to be listed on the stock market also indicates the maturity and success of IT industry [22].

IT Exports: The level of exports from Thailand's IT industry, most specifically the hardware industry, is impressive when compared with other developing countries. In 1998, the value of hardware exports was reported to be as high as 8,263 million US dollars [60]. A breakdown of hardware industry exports is: computers and parts 7,609 million US dollars; Telecommunication equipment 531 million US dollars; and communications and radar 123 million US dollars [60]. Thailand ranks seventh among the world's major computer and parts exporters (Yearbook of World Electronic Data 2000 Vol. 2). 
High Technology Exports: In 2001, high technology exports valued at 38,264 million US dollars accounted for almost 70 percent of the total manufactured exports and almost 60 percent of total exports [10]. The percentage contribution of high technology exports in Thailand is impressive. It surpassed many developed countries; for instance, Finland and New Zealand have a contribution of high technology exports to total manufactured exports in 1997 of only 26 percent and 11 percent, respectively [75].

Stock Exchange Listings: The number of IT firms listed on the stock market is considered to be one of the key indicators of the success and maturity of the industry [22]. Thirty-one IT companies are listed on the Stock Exchange Thailand. Of this total, thirteen companies are in the communication sector, ten companies in electrical products and computer sector and nine companies are in the electronic components sector. The large IT companies are mainly those in the communication sector, such as Thai Telecom and Telecommunication, Shin Satellite and Jasmin International. Unfortunately, there are no Thai IT companies listed on foreign stock markets.

Summary. Thailand's IT industry success is largely the result of its hardware industry, while the software industry is still at an early stage of development. This unbalanced success of the hardware and software industries can be expected to be seen in developing countries [46]. However, some developed countries also face a similar situation; for instance, the New Zealand software industry is considerably successful but its hardware industry is modest. In this study, we consider that Thailand has a reasonably successful IT industry. Given that Thailand is a developing country that used to rely heavily on primary products for many decades, the country has shown a remarkable improvement in becoming a major exporter of high-technology and IT products that are internationally accepted.

\section{d. Mediating Factors}

In this study, there are six mediating factors, with the last factor, IT related foreign direct investment, expected to be influenced by the first five mediating factors (geographical location, domestic IT use, government policies and regulations, information infrastructure and human resource); each having IT industry success as a consequence.

\section{Geographical Location}

In the previous study of Ein-dor et al [22], geographical location, although important, is considered to not affect IT industry success in small developed countries. In this study, the factor is reconsidered to find out whether the previous conclusion applies also to developing countries. The data on geographical location are presented in Table 4.

\begin{tabular}{|l}
\hline Location Related Factors \\
\hline Geographical Location \\
Physical Location \\
Neighbouring countries \\
IT Market Proximity: \\
Europe
\end{tabular}

\begin{tabular}{|c|c|}
\hline Thailand & \\
\hline $\begin{array}{l}\text { Middle o } \\
\text { Myanmaı }\end{array}$ & $\begin{array}{l}\text { inland } \\
\text { Imbodia, Malaysia }\end{array}$ \\
\hline Distance & Trade \\
\hline Far & Middle \\
\hline
\end{tabular}


North America

Asia and Pacific
Far

Close
High

Most

Table 4: Location Related Factors (adapted from Ein-dor et al [22]; Watson and Myers [75])

Location $\rightarrow$ Hardware Industry: Favourable geographical location is a common characteristic found in most of the countries that have a successful hardware industry [19]. Given that Thailand is situated in the middle of mainland South East Asia, with the availability of three modes of international transportation (air, ground and sea), its location is conducive to the conduct of international trade. Thailand takes advantage of its location by engaging in substantial trade exchange with ASEAN countries, of which Thailand is a member. According to the Trade Statistic Centre [cited in 72], Thailand exported more than 40 percent and approximately 3 percent of its computer and parts production to Singapore and Malaysia respectively. Apart from ASEAN countries, other countries in East Asia such as Japan, Hong Kong and China are also important export markets for computers and parts, with exports to Japan accounting for approximately 9 percent [72]. The other major export destinations for the industry are the USA, Netherlands and United Kingdom which hold shares of around 17, 8 and 5 percent respectively [72].

In addition, imports of electronic products, especially computer parts and accessories, and integrated circuits are mainly from the United States, Japan, Singapore, Malaysia and Taiwan [72]. The above evidence of Thailand's IT market's proximity and its heavy trade activity with neighboring countries show that its location has supported IT industry success in Thailand. Therefore, it may be concluded that geographical location is one of the factors explaining Thailand's hardware industry success.

Location $\rightarrow$ FDI $\rightarrow$ Hardware Industry: There are many factors that MNCs consider when selecting a host country to locate their production base; such as availability of raw material, low-cost labor and access to a domestic market $[20,61]$. There are many reasons why MNCs choose Thailand as a production base for hardware industries. One reason is its IT market proximity; providing access to China and the rest of the region [73]. In addition, the integration of the ASEAN countries make Thailand and the other member countries more favorable production bases, due to a large, and growing, potential IT market with free trade in IT goods and services [61]. Thailand and Malaysia have been chosen as production bases for HDD sub-assembly [39] as they offer low cost labor and are close to a more mature industry in Singapore, where HDD components and parts are mainly shipped for final assembly [15]. Thailand's geographical location therefore could be one of the factors supporting the choice of the country as a production base for MNCs. Consequently, if the presumption of FDI influencing IT industry success is true, location also has an indirect impact on the IT industry's success in attracting FDI. 


\section{Domestic IT Use}

To measure the country's use of IT the composite of sub-variables (national IT spending, the number of computers installed and the volume of national telecommunication use) established by Ein-dor et al (1997) is adapted and applied to this study. A summary of these data is presented in Table 5.

\begin{tabular}{|l|l|}
\hline Domestic IT Use & Thailand \\
\hline Internet users/100people & $12.74(\mathrm{a})$ \\
\hline IT spending & \\
\hline Total IT Spending (US \$ millions) & $1,511(\mathrm{a})$ \\
\hline IT spending as a percentage of GDP & $1.2(\mathrm{a})$ \\
\hline ICT expenditure as percentage of GDP & $2.13(\mathrm{~d})$ \\
\hline Personal Computers per 100 persons & $3.795(\mathrm{a})$ \\
\hline Telecommunications Revenues ( US \$ millions) & $64,781(\mathrm{f})$ \\
\hline Telecommunication revenues per capita (US \$) & 1067 (f) \\
\hline
\end{tabular}

Table 5: Domestic IT Use (adapted from Ein-dor et al [22]; Watson and Myers [75])

Sources: National Information Technology Committee Secretariat (NITC), The World Competitiveness Yearbook,

US Department of Commerce: International Trade Administration, World Development Indicator 2001, The Association of Thai Computer Industry (ATCI), National Electronics and Computer Technology Centre (NECTEC) note : (a) = yr 2002, (b) = yr 2001, (c) = yr 2000, (d) = 1999, (e) = 1998, (f) =1997

IT Spending: According to ATCI [6], Thailand's IT market revenue increased steadily until the financial crisis of 1997-8. In 1995, the market revenue was USD 1,247 million, increasing to USD 1,422 million in 1997, before falling to USD 649 million [6] as the impact of the financial crisis and local currency devaluation was felt. The growth rate of the IT market was as high as $39.9 \%$ in 2000 due to the awareness of the Year 2000 problem and declind by 15.9\% in 2001 In 2001, the percentage breakdown for each segment of the IT market was as follows: hardware 63 percent, software 18 percent, services 19 percent [9]. The software market seems to be the fastest growing market as the government becomes more concerned with software piracy issues and directly supports software companies in many ways. In 2002, the software market increased by 23.6 percent over 2001 [8].

Internet Use: In 2000, there was 2.08\% of Internet users in Thailand, less than one-third of Malaysia's at $6.88 \%$ [77]. Thailand was still far behind compared with developed countries, which normally have more than ten percent of Internet users.

Personal Computer Penetration: Thailand has personal computer (PC) penetration rates of only 3.795 percent, which is only about one-third of Malaysia's (10.314 percent). Yamada (2001) pointed out that the PC penetration rate in Thailand is hindered by the cost of a PC being more than twice or three times as much as the monthly income of most people. Nonetheless, the PC penetration in Thailand is expected to increase rapidly and to reach 2.5 million in 
2003 [80]. This may be the result of the reduction in taxes and tariffs on IT products and the trend toward cheaper IT products.

The Use of Telecommunications: Telecommunication revenues in Thailand were relatively high (almost USD 65,000 million US dollars). Telecommunication revenues per capita were USD 1,067 in 1997 which accounted for more than fifty percent of GDP per capita. This may reflect the heavy use of telecommunication in Thailand but in part the high revenue may come from the high cost of telecommunication services.

Summary. Domestic IT use in Thailand, although reasonably high when compared with other developing countries, is not outstanding. In fact, it is relatively low when compared with IT use in developed countries. Therefore, as with previous research on small developed countries, domestic IT use does not appear to be significant enough to influence IT industry success in a developing country either. Moreover, foreign companies that invested in Thailand seems to focus on external markets rather than the domestic market [31]. Although there are some foreign software companies, for example IBM, Oracle and Microsoft, which target the domestic market (like government and large scale companies), this does not seems to explain IT industry success, which is dominated by the hardware industry. As a result, domestic IT use does not directly or indirectly impact IT industry in Thailand.

\section{Government Policies}

Table 6 presents the IT industry related government policies.

\begin{tabular}{|l|l|}
\hline Government Policies & Thailand \\
\hline IT policies & Yes \\
\hline IT Strategy & National IT policy \\
\hline Type of Promotion of IT Use & National IT policy \\
\hline Type of Promotion of IT Development & High \\
\hline IT priority & High \\
\hline IT Use Priority & 1 \\
\hline IT Development Priority & 2 \\
\hline Government IT Organisations & \\
\hline Number of Policy Setting Organisations & \\
\hline Number of Advisory Organisations & \\
\hline Research and Development & $147(\mathrm{~d})$ \\
\hline Extent of R\&D & 0.13 \\
\hline Gross Domestic Expenditure on R\&D (US \$ millions) & $103(\mathrm{e})$ \\
\hline R\&D expenditure as a percentage of GNI(1987-1997) & \\
\hline Scientists and Engineers in R\&D/million people & $29(\mathrm{~d})$ \\
\hline Performance of R\&D & $71(\mathrm{~d})$ \\
\hline Percentage of R\&D Performed by the Private Sector & \\
\hline Percentage of R\&D Performed by the Public Sector & \\
\hline
\end{tabular}

Table 6: Government Policies (adapted from Ein-dor et al [22]; Watson and Myers [75])

Sources: The World Competitiveness Yearbook 2001, World development indicators 2002 note : (a) = yr 2002, (b) = yr 2001, (c) = yr 2000, (d) = 1999, (e) = 1998, (f) =1997 
National IT Policies: Thailand's first national IT plan, called IT 2000, was launched in 1995 by the National Information Technology Committee (NITC), which in turn was established under the National Electronics and Computer Technology Centre (NECTEC) in 1992 with responsibility for developing IT policy [48]. This first IT policy focused on three main areas: building a national information infrastructure; developing IT manpower; and strengthening government services and support for the information industry [80]. A number of projects have been initiated to implement these policies. Most of the projects focus on building an IT society; such as SchoolNet Thailand launched for the purpose of increasing students' opportunity to learn [36]. Only a few are directly aimed at the development of the IT industry. The development of a legal infrastructure is one of the few that is. That project is aimed at introducing new laws to support the application of information and communication technology (ICT) in the country. The other project important to the IT industry is Software Park Thailand (SWP), set up for the purpose of promoting the software industry in Thailand. The aims of this organization are to offer infrastructure and environment to support software entrepreneurs; to enhance the skills of IT professionals; and to establish a business to business exchange on both a national and international basis [63]. Apart from SWP, NECTEC also acts as an advisory organisation for electronics manufacturers. NECTEC is responsible for ensuring the country's competitiveness in Computer and Electronics as well as stimulating the use of IT. In 2001, the second National IT plan "IT 2010" was launched, before the first National IT plan reached it goals. IT 2010 has similar principles to the previous national IT policy: building human capital; promoting innovation and investing in information infrastructure; and promoting the information industry [71]. Thailand's national IT policies seem to be introspective; with a main focus on development inside the country, and lacking an outward focus [14].

The Extent of Research and Development (R\&D): Thailand's expenditure on R\&D is relatively low. Its total public expenditure on university research is claimed to be less than that of a large engineering department in a US university [TDRI cited in 1]. Between 1987 and 1997, the country's R\&D expenditure accounted for only 0.13 percent of Gross National Income (GNI), which is less than the average of public expenditure on R\&D in both East Asia and the Pacific (1.2 percent of GNI) and lower middle income countries (0.6 percent of GNI) [77]. In 2001, the government's total R\&D expenditure accounted for 0.17 percent of GDP and the amount of R\&D expenditure on Science and Technology accounted for 0.05 percent of GDP [50]. Even though Thailand exports large numbers of hardware products, it was notable that no research centre existed in the industry until the establishment of Technology Micro Electronic Centre (TMEC) in 1995 under the Nation Electronics and Computer Technology Centre (NECTEC). Moreover, the low number of scientists and engineers in R\&D and the number of patents also reflect less effective government support for R\&D. The number of scientists and engineers in R\&D per million people in Thailand is only 103 persons, which is surprisingly low when considered together with the value of its export of high technology products.

Investment Promotion Policy: The Thai government provides a range of benefits, such as income tax exemption, import duties reduction and a free entry permission of expatriate experts and technicians, to foreign investors in a 
number of industries including, the computer hardware industry [41]. Moreover, further benefits such as 'full tax exemption on imported inputs and a refund of all taxes paid in the process of export production' [44 p. 47] have been given since the enactment of the Export Promotion Act in 1972. The export-oriented policy was successful in attracting a number of world-class companies in the hardware industry, such as Seagate, IBM and Fujitsu, to invest in Thailand. The Asian Wall Street Journal [11] indicated that the investment promotion policy is one of the reasons attracting many Japanese investors to invest in Thailand. Once the MNCs became established, they stimulated the hardware industry by creating demand for an indigenous supply base for components. This mechanism is significant to the growth of the hardware industry in Thailand.

To strengthen the Thai software industry, a range of incentives are given to both foreign and local companies through the Board of Investment (BOI). These incentives include corporate income tax exemption for eight years, exemption from import duties for machinery, a 25 percent deductible from net profits for infrastructure installation costs, and no limit to the percentage of foreign ownership [4, 73]. Furthermore, the Software Park provides facilities and a number of supports such as low-cost rental space, a business and information unit, a training unit, software testing and certification units, and a software incubator unit for software companies [4]. Thailand has shown its efforts to link its IT industry with global markets by attracting foreign firms, via the BOI, to invest in the country. Currently, more than 163 software companies invest in Thailand through investment promotions by the BOI [11].

Trade Policy: Thailand is a member of ASEAN, which facilitates the trade amongst ASEAN countries. The participation of Thailand in international trade agreements is another facilitator that supports the growth of its IT industry. The list of IT products receiving reduced tax ranges from finished goods (e.g. computers) to components and peripherals (e.g. integrated circuits). Tangkitvanich [cited in 64] pointed out that this agreement can bring benefits to local IT development in three ways. Firstly, Thailand can export more computers and peripherals. Secondly, IT product users in Thailand benefit from consuming less expensive products. Finally, as the IT industry grows, there will be an increasing rate of employment. However, Sooksiriserikul [18] argued that locally produced IT products may be uncompetitive as the prices of imported products may become cheaper than local products, if import tax for raw products is maintained while import tax for finished goods is zero. Nevertheless, in general, imported parts and raw materials used for producing IT products for export are given tax exemptions [Meepokee cited in 64].

Summary. Government policy through the support of R\&D seems to be the least effective among the four types of policies and seem to have limited contribution to the success of the IT industry in Thailand. Moreover, even though government IT policies have shown a heavy commitment by the government to the importance of the use and development of IT, these policies were initiated less than ten years ago. Therefore, they may not be significant enough to entirely explain the success of the industry. On the other hand, investment promotion policy and trade policy do appear to have contributed to the growth of the IT industry by welcoming foreign companies and encouraging local companies to invest in the industry. We conclude that government policies, to some extent, have contributed to Thai IT industry development, however, there are still some steps (e.g. R\&D promotion) that the government could take in 
order to achieve a higher level of success. In addition, Thailand has had considerable success in attracting foreign direct investments from MNCs, suggesting that government policy has had some impact on investment on IT-related FDI.

\section{Human Resources}

Table 7 presents the results for human resources in Thailand.

\begin{tabular}{|l|l|}
\hline Human Resources & Thailand \\
\hline Ethnic groups & $\begin{array}{l}\text { majority: Thai } \\
\text { minority: Chinese, Malays, Lao }\end{array}$ \\
\hline Official languages & Thai \\
\hline Life expectancy & $69.4(\mathrm{c})$ \\
\hline Infant mortality/1000 live births & $28(\mathrm{~d})$ \\
\hline Literacy & \multicolumn{2}{|l|}{} \\
\hline adult & $95 \%(\mathrm{~d})$ \\
\hline youth & $98.5 \%(\mathrm{~d})$ \\
\hline Number of IT related field enrolments* & $8,610(\mathrm{~b})$ \\
\hline Number of IT Related Graduates ** & 24,867 (e) \\
\hline Value added per worker in manufacturing \$ per year('95-'99) & 19,946 \\
\hline Labour cost per worker in manufacturing \$ per year('95-'99) & 2,705 \\
\hline Education Policies & \multicolumn{2}{|l|}{} \\
\hline Total Education Expenditure as percentage of GNP & 4.8 (g) \\
\hline Total Education Expenditure as percentage of government expenditure & $25.4(\mathrm{~d})$ \\
\hline School Education & $272(\mathrm{a})$ \\
\hline Number of computer installed in Education (thousands) & $13.5(\mathrm{a})$ \\
\hline School Internet Access Percentage & $1,522,142(' 97 / 98)$ \\
\hline Tertiary Education & $22 \%(\mathrm{~g})$ \\
\hline Number of students enrolled in Tertiary Education & $18 \%$ \\
\hline Gross enrolment ratio in tertiary education & \\
\hline Science and engineering students/total tertiary students (1987-1997) & \\
\hline
\end{tabular}

Table 7: Human Resources (adapted from Ein-dor et al [22]; Watson and Myers [75])

Sources: The World Competitiveness Yearbook 2001, UNESCO Statistical Yearbook 1999, World Development Indicators 2001, NITC [53]

*this number is calculated from the report of Thai public universities under Ministry of University Affair [28] which does not include universities that are not under the ministry

**this number is included graduates at lower, higher and bachelor degree from both private and public university in 1998

Note: (a)= yr 2002, (b)= yr 2001, (c)= yr 2000, (d)= yr 1999, (e)= yr 1998, (f)= yr 1997, (g)= yr 1996

Education Policy: According to UNESCO (1999), Thailand's percentage of public expenditure on education per Gross National Product (GNP) is 4.8, which is almost at the same level as Malaysia's (4.9). Even though the percentage of public expenditure on education is not as high as in developed countries like Finland and New Zealand (7.5 and 7.3, respectively), it is higher than some developed countries, for example Japan, Korea and Singapore (3.6, 3.7 and 3.0, respectively), and the other developing countries in the region (UNESCO, 1999). Although this may be 
because populations in some of the above developed countries do not necessarily rely on heavy subsidies from government, it does reflect the importance of education to the Thai government. The education sector receives high priority from the government, as can be seen from the education sector receiving the largest share of total public expenditure since 1991. In 2000, 25 percent of the government’s budget was spent on the education sector [30].

School Education: Primary education in Thailand is compulsory; all children aged from six to twelve have free access to primary school. Thailand's literacy rate, at 95 percent, is among the highest in Southeast Asia [5]. In 2000, 77 percent of primary schools have PCs installed and only 2.2 percent have access to the Internet [30]. According to Kaewsaiha [33], on average there are only 2.26 computers per primary school. In 2000, 91 percent of secondary schools have access to computers and 44 percent have access to the Internet [24]. These schools have an average of 19 computers per school. This equates to one PC for every 53 students in secondary education [33]. It is expected that by the year 2003 all secondary schools will be provided with PCs which are connected to the Internet [51]. The SchoolNet Thailand project, launched accompanying national IT policy, has resulted in 4,550 schools from a total of 33,724 being connected to the Internet. With support from Telephone Organization of Thailand, these schools are charged only the local call cost per connection (at eight US cents per call), with no Internet access charge regardless of where the schools are in the country [24].

Tertiary Education: At present, there are 20 public universities and 33 private universities in Thailand under the Ministry of University Affairs. At the University level, all institutions are connected to Internet [24]. In 2000, only thirty nine percent of secondary school students continued on to study in tertiary education [24]. Of this number, 18 percent study in Science and Engineering [74]. Thailand's proportion of students going on to tertiary education is relatively low compared with Malaysia, Singapore and Korea where ninety percent of secondary schools students further their education [60].

IT Workers: The number of IT graduates in Thailand is increasing steadily, with an average growth of 19 percent during 1992 to 1998 [53]. In 1998 there were 24,867 IT professionals in Thailand, among whom 42.8 percent had a bachelor degree or higher [53]. The total number of IT workers in both the public and private sectors is 77,816 persons in 2001 [53]. Of this number, approximately 20,000 persons are software professionals [SWP cited in 50].

Human Resource Gaps: While the software market has grown tremendously in Thailand [8], the country appears to have a relatively small number of local software and services companies. In a report by Kirkman et al. [37], Thailand ranks 64 out of 75 countries in the competitiveness of the domestic software market, and ranks 67 out of 75 countries in the availability of specialised IT services [37]. These authors contend that the lack of IT workers seems to impede the growth of the software industry more than the hardware industry in Thailand. There are two reasons that why a shortage of IT workers affects the software industry more. Firstly, while the hardware industry requires a wider range of human resource (from semi-skilled labor to engineers), the software industry concentrates more on the graduates with high levels of computer skills. As a result of the low proportion of students going on to university study and the 
limited number of them studying in IT-related fields, the software industry struggles to expand. Secondly, the growth of the hardware industry is largely driven by investments from foreign companies and there is less FDI in software companies. The availability and creativity of local IT manpower, therefore, is more crucial. Although there seems to be a shortage, the quality and cost of Thailand's labor is often cited as a factor that attracts foreign investment into the hardware industry [11, 20, 65].

Summary. Although the attempts of the government to promote education in Thailand can be seen, the ratio of students continuing their studies in the universities is still low and the shortage of IT human resource can be attributed to this. Therefore, we conclude that human resource itself does not directly contribute to the success of the IT industry. On the other hand, Thailand is successful in providing basic literacy, which is necessary for further development of human resource; either to build skilled labor or university graduates. The literacy rate in Thailand is relatively high compared with other developing countries in the region. Moreover, the availability of university level graduates in engineering, and technical college level graduates makes Thailand attractive to foreign investors [65]. This advantage becomes more significant when comparing cost with the quality of workers [11].

\section{Infrastructure}

Although Thailand is considered a developing country, both the country's existing general and telecommunication infrastructure are relatively developed. For telecommunication infrastructure, the country provides both satellite and submarine/terrestrial cable network links throughout the country and with the rest of the world. Thailand contains three international satellite earth stations providing international connections via the satellites of the International Telecommunications Satellite Organization (IntelSat), global mobile satellite communication through the InmarSat (the International Mobile Satellite Organization) satellite system, domestic satellite services from 30 domestic satellite earth stations around the country, six submarine and terrestrial cable network systems including an optical fibre network linking Thailand to Asia-Pacific, Europe, Africa and Australia [54]. The country seems to be one of the region's leading adopters of technology, however, there are problems to be solved in respect of service quality, network utilization and the telecommunication regulatory regime [69]. According to the National IT Committee, the country does not currently require further significant investment in infrastructure as the existing fibre-optic network is only operating at ten percent of capacity. A summary of data on Thailand's infrastructure is presented in Table 8.

\begin{tabular}{|l|l|}
\hline Infrastructure & Thailand \\
\hline Telecommunication Infrastructure & \\
\hline Telephone mainlines per 100 people & $9.2(\mathrm{c})$ \\
\hline Waiting list (thousands) & $415.2(\mathrm{c})$ \\
\hline Mobile phones per 100 persons & $5.0(\mathrm{c})$ \\
\hline Secure Technology Assets (Secure Servers) & 116 \\
\hline Telecommunication investment as \% of GDP & 0.71 \\
\hline Annual Telecommunication investment (US \$ million) & $6,158(\mathrm{f})$ \\
\hline Five years investment in Telecommunication (US \$ million) & $2,025.70(\mathrm{e})$ \\
\hline Internet Hosts per 100 people & 0.065 (c) \\
\hline
\end{tabular}




\begin{tabular}{|l|l|}
\hline Monthly off-peak Internet access charge & \\
\hline Service provider charge (\$) & 9 (b) \\
\hline Telephone call charge (\$) & 0.75 (b) \\
\hline Cost of local call \$ per 3 minutes & 0.07 (b) \\
\hline Outgoing traffic minutes per subscriber & 64 (c) \\
\hline Cost of call to US. \$ per 3 minutes & 2.50 (d) \\
\hline General Infrastructure & \\
\hline Electric power & 1,352 (d) \\
\hline Consumption per capita kwh & 8 (d) \\
\hline Transmission and distribution losses \% of output & 14 (d) \\
\hline Quality of highways rank (of 75 countries) & $35(\mathrm{~d})$ \\
\hline Quality of port facilities and waterways rank (of 75 countries) & 29 (d) \\
\hline Quality of air transport rank (of 75 countries) & \\
\hline
\end{tabular}

Table 8: Infrastructure (adapted from Ein-dor et al [22]; Watson and Myers [75])

Sources: World Development Report 2000/2001, US Department of Commerce: ITA, World Development Indicators 2002, International Telecommunication Union: Yearbook of Statistics, World Economic Forum: The Global Information Technology Report 2001-2002

Note: (a)= yr 2002, (b)= yr 2001, (c)= yr 2000, (d)= yr 1999, (e)= yr 1998, (f)= yr 1997

Telecommunication Access: By 2000, Thailand still had a relatively low level of teledensity of 9.2, and an average of five mobile phones per one hundred population. This was less than half of Malaysia's, which is 19.9 for teledensity, and 21.3 for mobile phones [77]. Thailand ranks 60 and 61 for fixed telephone lines and mobile phones, respectively, among 75 countries [37]. Nonetheless, most companies are concentrated in Bangkok (the capital city) and the nearby prefectures, where the teledensity of Thailand's largest city is much higher, at 38.4 per hundred inhabitants [77]; a sufficient level to support the industry's growth. This figure is comparable with Singapore, which has a teledensity of 48.4 [77]. By this measure, Thailand ranks higher, at 34 of 75 countries in the number of telephone lines available to business [37].

Currently, Thailand expects the privatization of its telecommunications industry to be completed by 2006. A number of foreign telecommunication companies, such as Nynex/Bell Atlantic of the United States, SingTel of Singapore, Telenor of Norway and Telekom Malaysia, have started to invest in several telecommunication service operators in Thailand.

Internet Access: Internet access has been available in Thailand since 1987; however, the use was limited to the academic realm. In 1995, Internet services became generally available in Thailand following the establishment of Internet Thailand as the first Commercial ISP [30]. Currently, there are only 18 ISPs operating in Thailand [30]. Thailand ranks 49 out of 75 countries in the level of sufficiency of ISP competitiveness to ensure high quality and low cost service. The monopolistic telecommunication sector seems to be one of the factors that are hampering the growth of Internet penetration in Thailand. Internet Service Providers (ISPs) have to give a 32 percent stake to the CAT in order to get a license, without receiving any capital investment from CAT [80]. Moreover, the mandatory use of CAT's expensive connection lines also contributes to high operation costs. The cost of leasing Internet lines in 
Thailand is six times higher than that of Hong Kong; four times that of Japan; and more than twice that of Malaysia and the Philippines [68, 70]. Consequently, the monthly service cost for Internet access in Thailand (after adjusting for Purchasing Power Parity) is higher than that of many of East Asian countries [52, 64], although relatively low amongst Southeast Asian countries [30]. In addition, the inefficient telecommunication sector also results in the limited number of Internet hosts and number of computers directly linked to the Internet. Internet hosts are used by the ITU as a measure of national Internet penetration rate [29]. Sooksiriserikul [18] indicated that 26 percent of Internet hosts had relocated to other countries due to the high Internet access costs in Thailand. In 2000, Internet hosts per 100 head of population in the country were just 0.065 , compared with 0.254 in Malaysia.

General Infrastructure: While telecommunication infrastructure is crucial to the development of the software industry, general infrastructure like power systems and transportation is important to hardware industry. Although Thailand does not have as advanced an infrastructure as Singapore or Malaysia, the country seems to have a better infrastructure than others in the region. Thailand ranks 33 out of 73 countries in the efficiency of its electrical system with 8.7 percent of electrical transmission and distribution lost from total output in 1998 and 8 percent in 1999 [37, 77]. These percentages seems high but, in fact, they are less than some advanced countries like Ireland, Hong Kong and New Zealand which have 9.2, 11.83 and 13.41 percent of power loss respectively, in 1998. This reflects the reliability of the electrical power system, which is important to investors in the hardware industry as an unreliable electrical supply can cause damage during manufacturing. Thailand ranks above the mean for the quality of air, ground and water transportation, ranking 29, 14 and 35 of 75 countries respectively [37]. This demonstrates a reasonably developed infrastructure that supports goods delivery through three modes of transportation.

Summary. The country's infrastructure is considerably developed and seems to be sufficient for the industry's development. Although the cost of Internet access and telecom services is relatively high and not universally available, these problems seem not to be a barrier to hardware industry growth, but may be influencing the success of the software industry in Thailand. Nonetheless, improvement should be expected following the privatization of the telecommunication sector. To some extent, Thailand, despite being called a developing country, seems to have reliable infrastructure that contributes to certain IT industry development. The limited access to the Internet and its high cost (compared with the cost of living) could be a factor that is impeding the adoption and development of IT. On the other hand, the reliable infrastructure does satisfy foreign investors and contributes to their decision to invest in the country.

\section{IT related Foreign Direct Investment}

Thailand's fast growing economy is claimed to be significantly driven by FDI [31, 59]. This FDI and economic growth have been found to have a positive correlation [55]. The impact of FDI on Thailand's exports was considerable and resulted in the country’s fast growing economy [31]. FDI inflows into Thailand have increased more than 15 fold between 1980 and 1997 [World Bank cited in 55]. The World Bank [cited in 55] also reported that Thailand received among the largest inflows of FDI of any developing country. Thailand ranks sixth in the top ten largest recipients of FDI among developing countries from 1988 to 1992, following China, Singapore, Mexico, Malaysia and Argentina 
[United Nations cited in 21]. During this period Thailand received USD 9,500 million of FDI inflow [United Nations cited in 21]. Table 9 below illustrates the extent of FDI in Thailand.

\begin{tabular}{|l|l|}
\hline Foreign Direct Investment & Thailand \\
\hline Software Industry Ownership & 51 \\
\hline Percentage of Thai company & 28 \\
\hline Percentage of Foreign company & 21 \\
\hline Percentage of Joint venture & \\
\hline Electronics Industry Ownership & 16 \\
\hline Percentage of Thai company & 45 \\
\hline Percentage of Foreign company & 39 \\
\hline Percentage of Joint venture & $6,213(\mathrm{~d})$ \\
\hline FDI, net inflows (US \$ millions) & $1.8(\mathrm{~d})$ \\
\hline Gross Foreign Direct Investment as percentage of PPP GDP & \\
\hline
\end{tabular}

Table 9: IT related Foreign Investment

Sources: World Bank country profile, World development indicator 2001, Board of Investment Thailand note : (a) = yr 2002, (b) = yr 2001, $(\mathrm{c})=$ yr 2000, $(\mathrm{d})=1999,(\mathrm{e})=1998,(\mathrm{f})=1997$

At the same time, the electronics industry and the electrical \& appliances sector (which includes electronic products, telecommunication equipment, computer components, software, etc) became more significant in Thailand's manufacturing industry. There were 1,539 foreign investment projects approved by the Board of Investment (BOI) from 1993-2002 in the Electronics industry and Electrical Appliances sector, valued at USD15,253 million. The share of foreign investment in this sector to total foreign investment projects by value during 1993-1997 (until the East Asian financial crisis) was 10.7 percent. This share increased significantly during 1998-2002, with the average being 25 percent of total foreign investment value. Moreover, in 1999 and 2000, the Electronics Industry and Electrical Appliance sector ranked first in terms of investment value, accounting for 37.3 percent and 28 percent of total foreign direct investment respectively. In the first half of 2002 investment from Japanese investors, the main source of foreign investment in Thailand was valued at USD 393 million, which accounted for 31 percent of total foreign investment promoted by BOI. The next largest investors were Singapore (USD 219 million) and the United States (USD 216 million) [11]. During the same period the Electronics Industry and Electrical Appliance sector received the highest value of foreign investment projects promoted by BOI, amounting to USD338 million [11].

The computer and parts segment is the leading area in the Electronics Industry and Electrical Appliance sector. The investment of foreign companies in the sector started during 1981-1985 and increased substantially in the 1990s [1, 72]. A consequence of increasing FDI was the increasing level of the sector's production. In 1985, the computer and parts sector's production was valued at USD 64 million. Six years later production had increased by almost thirty times to USD 1,908 million and within thirteen years by more than one hundred fold to USD 7,488 million [57]. This presence of FDI also explains the phenomenon of a high level of high-technology product exports, but a relatively low number of scientists and engineers engaged in R\&D and the low number of patents in Thailand. The Thai hardware 
industry is clearly dominated by foreign and joint venture companies. Seagate alone exported hard disk drives that accounted for 4 percent of Thailand's total exports [20].

In addition, the ownership of the Electronics industry affirms the dominance of foreign companies in Thailand. In the Electronics industry 16 percent are Thai firms, 45 percent are foreign firms and 39 percent are joint ventures [12]. These statistics demonstrate that FDI has had a significant role in the Thai IT industry, especially in the Electronics industry (which includes the computer hardware sector).

In contrast, the effect of FDI on the software industry has not resulted in high production or exports by this industry. This is probably due to the foreign software companies' investments in Thailand being focused only on serving the domestic demand, rather than using Thailand as a production base like the hardware industry. The ownership of the software projects promoted by BOI were as follows: 51 percent Thai companies, 28 percent foreign companies and 21 percent joint ventures [12].

Summary. FDI, which underpinned double-digit growth in Thailand during 1987-1990 [31], appears to be a significant factor contributing to the hardware industry's success. The growth of hardware production and exports appears to have a positive correlation with FDI inflows into the country. Moreover, the majority ownership by foreign firms and joint ventures in the hardware industry illustrates the domination of FDI in that sector. We conclude that FDI is a factor that impacts IT industry success in Thailand and that geographical factors, government policies, human resources and infrastructure have indirect impact on IT industry success in Thailand through FDI.

\section{DISCUSSION AND IMPLICATIONS}

This study found differences in the factors that affect IT industry success in developed countries as compared to a developing country. It reflects that countries with different levels of economic development (developed versus developing countries) may be affected by different factors or may be affected by the same factors in differing ways. A summary of the study's findings is presented in Table 10 below.

\begin{tabular}{|c|c|c|c|}
\hline Factor & $\begin{array}{l}\text { Direct effect to } \\
\text { IT industry }\end{array}$ & $\begin{array}{l}\text { Indirect effect to } \\
\text { IT industry }\end{array}$ & $\begin{array}{l}\text { Literature supporting the } \\
\text { relationships }\end{array}$ \\
\hline $\begin{array}{l}\text { 1. Location related } \\
\text { factor }\end{array}$ & $\begin{array}{l}\text { Location } \rightarrow \text { IT industry } \\
\text { Supported } \\
\text { Connected to mainland } \\
\text { Southeast Asia } \\
\text { Close to major trade } \\
\text { partners }\end{array}$ & $\begin{array}{l}\text { Location } \rightarrow \text { FDI } \rightarrow \text { IT } \\
\text { industry } \\
\text { Supported } \\
\text { Provides access to } \\
\text { ASEAN } \\
\text { Close to investors eg. } \\
\text { Japan, Singapore and }\end{array}$ & $\begin{array}{l}\text { Dedrick et al (1995), } \\
\text { Mansell (1999) }\end{array}$ \\
\hline
\end{tabular}




\begin{tabular}{|c|c|c|c|}
\hline & & Taiwan & \\
\hline 2. Domestic IT use & $\begin{array}{l}\text { Domestic IT use } \rightarrow \text { IT } \\
\text { industry } \\
\text { Not Supported } \\
\text { Larger external market }\end{array}$ & $\begin{array}{l}\text { Domestic IT use } \rightarrow \text { FDI } \\
\rightarrow \text { IT industry } \\
\text { Not Supported } \\
\text { Export oriented FDI }\end{array}$ & $\begin{array}{l}\text { Ein-dor et al (1997), Watson } \\
\text { and Myers (2001) }\end{array}$ \\
\hline 3.Government Policies & $\begin{array}{l}\text { Government policies } \rightarrow \\
\text { IT industry } \\
\text { Weak Support } \\
\text { Successful Investment } \\
\text { promotion policy } \\
\text { Relatively late issued IT } \\
\text { policies } \\
\text { Low R\&D support }\end{array}$ & $\begin{array}{l}\text { Government policies } \rightarrow \\
\text { FDI } \rightarrow \text { IT industry } \\
\text { Supported } \\
\text { Successful Investment } \\
\text { promotion policy } \\
\text { Trade policy }\end{array}$ & $\begin{array}{l}\text { Ein-dor et al (1997), Watson } \\
\text { and Myers (2001), Kraemer } \\
\text { and Dedrick (1997), Tallon } \\
\text { and Kraemer (1995) }\end{array}$ \\
\hline 4. Human Resource & $\begin{array}{l}\text { Human Resource } \rightarrow \text { IT } \\
\text { industry } \\
\text { Not Supported } \\
\text { Shortage of IT personal }\end{array}$ & $\begin{array}{l}\text { Human Resource } \rightarrow \text { FDI } \\
\rightarrow \text { IT industry } \\
\text { Supported } \\
\text { Good for foreign } \\
\text { investors when comparing } \\
\text { cost with quality }\end{array}$ & $\begin{array}{l}\text { Kraemer and Dedrick } \\
\text { (1997), Mansell (1999) }\end{array}$ \\
\hline 5. Infrastructure & $\begin{array}{l}\text { Infrastructure } \rightarrow \text { IT } \\
\text { industry } \\
\text { Weak Support } \\
\text { Lack of universal access } \\
\text { of Internet and High cost }\end{array}$ & $\begin{array}{l}\text { Infrastructure } \rightarrow \text { FDI } \rightarrow \\
\text { IT industry } \\
\text { Supported } \\
\text { Reliable infrastructure }\end{array}$ & $\begin{array}{l}\text { Kraemer and Dedrick } \\
\text { (1997) }\end{array}$ \\
\hline 6. IT related FDI & $\begin{array}{l}\text { FDI } \rightarrow \text { IT industry } \\
\text { Supported } \\
\text { Hardware industry is } \\
\text { leading by foreign } \\
\text { companies }\end{array}$ & & $\begin{array}{l}\text { Kraemer and Dedrick } \\
\text { (1997), Tallon and Kraemer } \\
\text { (1995), Dedrick et al (1995) }\end{array}$ \\
\hline
\end{tabular}

Table 10: Summary of Findings and Supporting Literature

From six originally proposed factors, four, namely geographical location, IT-related Foreign Direct Investment and, to a lesser extent, government policies and infrastructure, were found to have a direct impact on IT industry success.

Firstly, geographical location is considered important to Thailand's success, even though this factor was suggested not to be a necessary factor to IT industry success for small developed countries [22]. Thailand has utilized its affiliation with ASEAN countries to its advantage by conducting much of its trade volume with member countries. Thailand's main exports of hardware products are destined for ASEAN countries, with Singapore being the largest importer [15, 
72]. Its geographical location, then, is considered to contribute to the growth of hardware industry in Thailand. This finding is supported by the studies of Dedrick et al (1995) and Watson and Myers (2001).

Secondly, government policies, through trade policy and investment promotion policy, seem to facilitate the growth of the hardware industry in Thailand. The government's success in promotion of IT in Thailand to its current state appears less obvious than those of its neighbors like Singapore and Malaysia. This is due to the relatively late announcement of IT policies in Thailand. Moreover, from some economists' point of view, Thailand's government seems to have been less interventionist in encouraging export-led industrialization than Japan's and four NICs' (Korea, Taiwan, Hong Kong and Singapore) governments are [56]. However, fewer restrictions and support from the government, together with the openness of the country to international trade and a wide range of tax incentives raised by government agencies appear to have some contribution to the growth of the IT industry. Nonetheless, the notion that government policy has direct impact on IT industry success is found to be only weakly supported, as a higher level of success, especially for the software sector, would seem to have been achievable if the government had initiated IT industry policy earlier and if it had also provided more support for R\&D.

Thirdly, the infrastructure of the country seems to be sufficiently available and reliable for operating manufacturing and software companies. However, universal access to the Internet has not yet been achieved in Thailand. This is due to the high cost of Internet access that results from the inefficient telecommunication regime. Removal of the limitations to Internet access could result both in increased adoption and development of IT. Moreover, the provision of universal access to computers should help increase the number of IT professionals. The suggestion that infrastructure has a direct impact on IT industry success, therefore, is considered weakly supported.

Finally, investment by foreign companies in the IT industry appears to be the most significant factor to the industry's success. Evidence, such as the low level of R\&D compared with the high volume of high-technology product exports, the low number of residents' patents and the small number of Thai nationality IT firms demonstrates the obvious dominance of foreign companies in the hardware sector, which is the leading contributor to the IT industry's success.

Furthermore, geographical location, government policies, infrastructure and human resources appear to contribute to the large investment by foreign companies in the country. As FDI is the key factor affecting Thailand's IT industry, these factors are also considered to have an indirect impact on IT industry success. The findings suggest that government policies and infrastructure make a stronger contribution by attracting FDI than by their direct contribution to IT industry success. On the one hand, human resource by itself is considered not to contribute to IT industry success, as there appears to be a shortage of sufficiently qualified IT professionals in the country [53]. On the other hand, for foreign investors, the quality of the available human resource is very attractive when compared with its cost.

These relationships are depicted in Figure 4. 


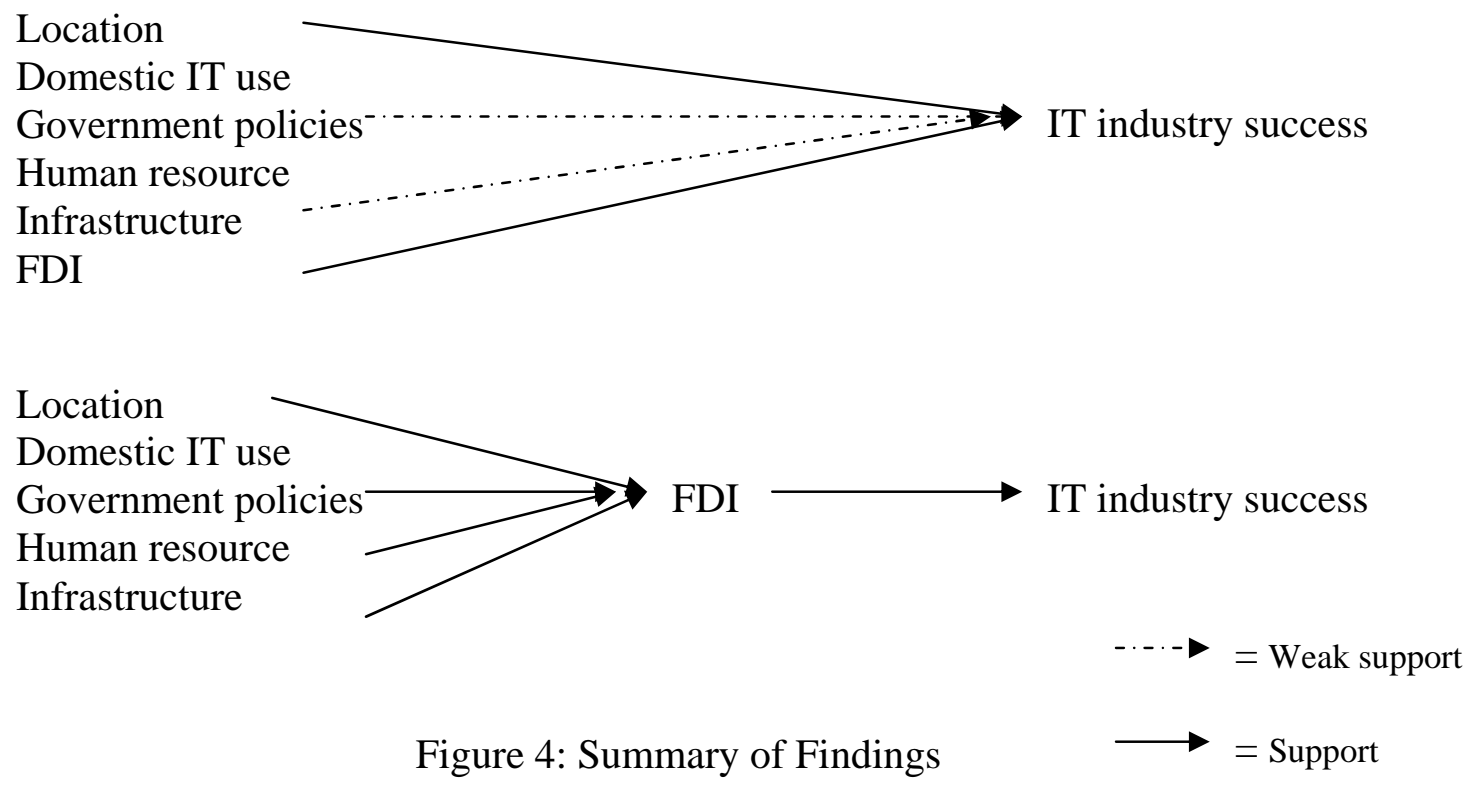

\section{Challenges for Thailand's IT Industry Development}

In order to develop the country's capability, Thailand should learn from developed countries. Factors that affect IT industry success in developed countries should be placed as the first priority for development. Even though Thailand's IT industry can be classified as successful based upon the criteria of Ein-dor et al's (1997) framework, the diffusion of IT in the country is low and it is concentrated in the populations of the big cities. Thailand's experience has been different from Singapore's where, although that country's IT industry also relies heavily on MNCs, it has been able to develop its human resources, infrastructure and policies to embrace technology.

There are two challenges for Thailand. Firstly, to achieve sustainable hardware industry success, the country needs to move into the more sophisticated aspects of the IT industry, such as fabrication and design. As stated earlier, Thailand is now facing competition for its position in the hardware industry's value chain. Many companies in the industry are engaging in assembling by utilizing the country low-cost labor. However, this advantage is not sustainable as a country's labor costs tend to increase along with the growth of economic development. In order to shift to the more sophisticated manufacturing tasks, the government needs to encourage and support the private sector's R\&D. The Finnish government, for example, stimulated $R \& D$ in private companies by providing tax incentives for R\&D expenditures [75]. More recently, the Thai government has taken some action on R\&D via TMEC, to drive the industry toward fabrication and design tasks [43]. Nonetheless, this has to be supported by increasing the number of well-educated professionals in the fields of IT, science and engineering. In addition, the government should support the emergence of indigenous firms. Until now, the government appears to have been less interventionist and this has limited IT firms to certain portions of the IT industry value chain. Foreign companies have largely driven the industry. 
The support of the government to increase the number of indigenous firms that engage in manufacturing of sophisticated products, such as IC design and wafer fabrication (upstream industry), could help to nurture the existing MNCs or indigenous firms that engage in IC packaging and PCB manufacturing (middle stream industry) [43].

Secondly, to be successful in the software industry, Thailand needs to provide universal access to telecommunication, for instance by increasing teledensity (found to be significant to software industry production [38]), and lowering Internet access costs. In addition, both the quantity and the quality of IT workers need to be improved to support the growth of the industry.

\section{Implications for Future Research}

This study examined IT industry success in Thailand. The framework used in this study needs to be tested in other developing countries to ensure the generalizability of the theory and also to achieve the iterative nature of explanationbuilding analysis. A comparison among countries could then be drawn, using the level of economic development as a control variable. Some of the factors adopted from previous studies, do not appear to impact IT industry success in developing countries, for example domestic IT use. This factor may be excluded from the model in the future. The employment of the framework of IT industry in small developed countries by researchers from many different disciplines is expected to help in grounding the framework from various perspectives [75]. Similarly, the present model could be employed by researchers from various disciplines, such as researchers in public policy. By doing so, new factors that contribute to the framework for developing countries may be discovered; the generalizability of the framework, therefore, should increase.

Moreover, this research adapted the Ein-dor et al [22] model, and that of Watson and Myers [75], where the success of an IT industry is largely measured by IT production and exports, while the breadth of production and the depth of technology [see 38, 41] were not considered. Future researchers may wish to consider including these two dimensions of IT products as criteria of IT industry success. This new research can be conducted by integrating the framework of Kraemer and Dedrick [38] with that of Ein-dor et al.

Furthermore, the affect of FDI on IT industry success may not be limited only to developing countries. Future research may also wish to consider FDI as a factor that may contribute to IT industry success in developed countries. In fact, the flows of FDI among developed countries themselves are higher than those available to developing countries. FDI in IT-related industries of developed countries may be investigated. Ireland is one of example of a developed country that has achieved success in its IT industry by encouraging heavy investment from foreign companies [see 67].

\section{CONCLUSION}

Information Technology is considered vital to a country's development, more so for developing countries, in the information technology era. It has become widely recognized as a tool that can enable leapfrog development in 
developing countries [18]. Currently, a number of developing countries have emerged as suppliers and exporters in the global IT industry, for example India, Malaysia, the Philippines and Thailand. Even though these countries have become significant in either the software and hardware markets, there seems to be limited IT industry research that has been done for these countries, especially for the purpose of further developing their IT industries.

The aim of this research was to examine the IT industry in a developing country - Thailand - to establish the factors that underlie its success.

From our analysis, we found that the investment of foreign companies into the IT industry is significant to the Thai IT industry, especially the hardware sector. This seems to be the key factor explaining how a developing country like Thailand became one of the world leaders in IT hardware exports. FDI provides elements needed for IT industry development that, in general, developing countries seem to lack (e.g. advanced technology, capital and skilled human resources). In addition, four out of five other factors, being geographical location, government policies, human resources and infrastructure, are found to have positive relationships with IT related to FDI. Thailand's geographical location provides access to ASEAN countries and attracts foreign companies to invest in the country. The country is open to international trade and foreign investment, which contributes to the large inflows of FDI. The abundance of low-cost labour also attracts MNCs seeking cost savings. Accepting that Thailand is a developing country, its infrastructure is generally superior to that of other developing countries and is relatively reliable for operating businesses. This factor also contributes to encouraging foreign investors.

To some extent, government policies seem to contribute to IT industry success by attracting investment into the country and, to a lesser extent, by the direct promotion of IT, but they fail to support the industry via spending on $R \& D$. The country's infrastructure appears to be reliable and conducive to operating manufacturing plants, however, the high cost of telecommunications could be a barrier to Thais's adoption of IT and consequently to software industry success.

Thailand is at the point where it has to develop its own technological capabilities to expand the range of IT industry in the country, in order to sustain its success. To do so, the development of the IT workforce needs to proceed for both the hardware and software sectors. The development of qualified IT professionals is especially important to the software industry. The country can enhance its advantage of relatively low-cost labor, if the pool of IT workers is increased. Universal telecommunication and Internet access is also required for the development of the IT workforce and industry generally. It is necessary that the government provides sufficient support for R\&D, as well as promoting $R \& D$ in the private sector, to drive the emergence of indigenous firms in new and more sophisticated IT manufacturing activities. 


\section{REFERENCES}

1.Abdulsomad, K. Thailand: Industrialization Through Foreign Technology, 52, Department of Economics, the University of Lund, (1994).

2.Anonymous Thai equities - time to get back on board. Asiamoney, (2000),

3.APEC, Thailand. 1994, Asia-Pacific Economic Cooperation:

4.Asia Computer Weekly Thailand parks smoothly into software development space, Asia Computer Weekly, February 8 1999,

5.AsianInfo, education/Literacy in Thailand. 2000, AsianInfo.org:

6.ATCI IT industry, The Association of Thai Computer Industry, (1999).

7.ATCI, IT Market Outlook. 2001, The Association of Thai Computer Industry:

8.ATCI, Executive Summary ICT Market Outlook 2003. 2003, ATCI, ATSI, INA:

9.ATCI Thai ICT Market by Industry Segments 2003, Association of Thai Computer Industry, (2003).

10.Bank of Thailand, Economic Data. 2003, Bank of Thailand:

11.BOI Foreign Direct Investment condition during the first half of year 2002, Board of Investment, Thailand, (2002a).

12.BOI The Electronic and Electrical Industry in Thailand, Board of Investment Thailand, (2002b).

13.Chen, J.-r. Foreign Direct Investment, International Financial Flows and Geography, in John-ren Chen, ed., Foreign Direct Investment, London, New York: MACMILLAN PRESS LTD, ST. MARTIN'S PRESS, INC., 2000, 6-33.

14.Corbitt, B. Exploring the Social Construction of IT Policy--Thailand and Singapore. Prometheous, 17, 3, (1999),

15.CSN \& Associates Parts and accessories of computer, CSN\&Associates, (2001).

16.CSN\&Associates Parts and accessories of computer, CSN\&Associates, (2001).

17.Davies, R., Thailand Capsule. 2002,

18.Davison, R.; Vogel, D.; Harris, R.; and Jones, N. Technology leapfrogging in developing countries - An inevitable luxury? Electronic Journal of Information Systems in Developing Countries, 1, 5, (2000), 1-10.

19.Dedrick, J.; Goodman, S.E.; and Kraemer, K.L. Little Engines that could: Computing in small energetic countries. Communications of the ACM, 38, 5, (1995), 21-26.

20.Doner, R.F., and Brimble, P. Thailand's Hard Disk Drive Industry, The Information Storage Industry Center, University of California, 02 October 1998 (1998).

21.Dumois, A., International Investment Theory. 1997, Washington DC.

22.Ein-dor, P.; Myers, M.D.; and Raman, K.S. Information Technology in Three Small Developed Countries. Journal of Management Information Systems, 13, 4, (1997), 61-89. 
23.Elmore, M., and Pereira, M., Riders of the storm. 1999, Electronic Business Asia:

24.Gray, V.; Kelly, T.; and Minges, M. Bits and Bahts: Thailand Internet Case Study, International Telecommunication Union, (2002).

25.Grossman, G.M., and Helpman, E. Innovation and Growth in the Global Economy. London: The MIT Press, 1992.

26.Hambrick, D.C., and Mason, P.A. Upper echelons: The organisation as a reflection of its top managers. Academy of Management Review, 9, (1984), 193-206.

27.Hasson, S.Z. Software Industry Evolution in a Developing Country: An In Depth Study, in Proceedings of Proceedings of the 33rd Hawaii International Conference on System Sciences, Hawaii, 2000.

28.Information Centre Report of Education in Universities under Ministry of University Affair, Ministry of University Affair, (2001).

29.ITU African Telecommunications Indicator, International Telecommunication Union, (1998).

30.ITU Bits and Bahts: Thailand Internet Case Study, International Telecommunication Union, (2002).

31.Jansen, K. External Finance in Thailand's Development: An Interpretation of Thailand's Growth Boom. New York: ST. MARTIN'S PRESS, INC., 1997.

32.Jomo, K.S. Growth and Structural Change, in K.S. Jomo, ed., Southeast Asia's Industrialization: Industrial Policy, Capabilities and Sustainability, New York: Palgrave Publishers, 2001.

33.Kaewsaiha, T., Learning Technology "To Reach the Unreached" in Thailand. 2002, UNESCO:

34.Kamaruding, A. Thailand: Industrialization Through Foreign Technology, 52, Department of Economics, the University of Lund, (1994).

35.Katz, R.L. The Information Society: An International Perspective. New York: Praeger Publishers, 1988.

36.Kiattananan, P., and Koanantakool, T., Schoolnet Thailand: An Information infrastructure of the future of Thailand. 1998, NECTEC:

37.Kirkman, G.S.; Cornelius, P.K.; Sachs, J.D.; and Schwab, K. The Global Information Technology Report: Readiness for the Networked World. Oxford University Press, 2002.

38.Kraemer, K.L., and Dedrick, J. National Technology Policy and the Development of Information and Organizations, Center for Research on Information Technology and Organizations (CRITO), University of California, (1993).

39.Kraemer, K.L., and Dedrick, J. ASIA Computer Report 1996: National IT Policy, CRITO, (1996).

40.Kraemer, K.L., and Dedrick, J., IT-Led Development in Singapore: From Winchester Island to Intelligent Island. 1997, Center for Research on Information Technology and Organizations and University of California, Irvine:

41.Kraemer, K.L., and Dedrick, J. National Technology Policy and Computer Production in Asia-Pacific Countries, Centre for Research on Information Technology and Organisations, (2001).

42.Kraemer, K.L.; Gurbaxani, V.; and King, J.L. Economic Development, Government Policy, and the Diffusion of Computing in Asia-Pacific Countries. Public Administration Review, 52, 2, (1992), 
43.Leemawattana, W. Electrical and Electronic Technology Toward Upstream Industry, Technology Promotion, Vol. 159, (2001), 37-49.

44.Lim, L.Y.C., and Fong, P.E. Foreign Direct Investment and Industrialisation in Malaysia, Singapore, Taiwan and Thailand. Paris: OECD, 1991.

45.Lunsche, S., The Tigers can show SA how to roar to prosperity. 1997, Business Times:

46.Mansell, R. Information and communication technologies for development: assessing the potential and the risks. Telecommunications Policy, 23, (1999), 35-50.

47.Masuyama, S., and Vandenbrink, D. Industrial Restruturing in East Asian Economies for the Twenty-first Century, in Seiichi Masuyama, Donna Vandenbrink, and Siow Yue Chia, ed., Industrial Restructuring in East Asia Towards the 21st Century, Tokyo: Institute of Southeast Asian Studies

Nomura Research Institute, 2001.

48.McDaniel, D. Electronic Tigers of Southeast Asia. Iowa: Iowa State University Press, 2002.

49.Miles, M.B., and Huberman, A.M. Qualitative Data Analysis. Second ed., An Expanded Sourcebook, London: SAGE Publications, 1994.

50.NECTEC Reference Data for ICT Master Plan Development, National Electronics and Computer Technology Center, (2002).

51.Office of the National Education Commission, Education in Thailand 2000-2001. 2000, UNESCO:

52.Palasri, S.; Huter, S.; and Wenzel, Z. The History of the Internet in Thailand, The Network Startup Resource Center, (1999).

53.Pantasen, A.; Sooksiriserikul, S.; Panyasawassut, C.; Pantawee, P.; and Gomonta, M. The report of demand on IT manpower of Thailand (Thai version), National Information Technology Committee, (2001).

54.Paul Budde Communication Pty Ltd Thailand-Telecommunications Infrastructure and Major Player, (2003).

55.Perkins, D.H.e.a. Economic of Development. 5th ed., WW.Norton\&Company, Inc., 2001.

56.Phongpaichit, P., and Baker, C. Thailand's boom. New South Wales: Allen \& Unwin, 1996.

57.Poh-Kam, W. ICT Industry Development \& Diffusion in Southeast Asia, in Proceedings of ASEAN Roundtable 2000 New Development Paradigms in Southeast Asia: The Challenges of Information Technology, 2000.

58.Public Relation Department, Thailand. 2000, Public Relation Department:

59.Rasiah, R. Southeast Asia's Ersatz Miracle, in K.S. Jomo, ed., Southeast Asia's Industrialization: Industrial Policy, Capabilities and Sustainability, New York: Palgrave Publishers Ltd, 2001.

60.Reed Electronics Research The Yearbook of World Electronics Data. Surrey: Reed Business Information Ltd.,, 2000.

61.Severino, R.C., Investing in ASEAN - New Factors to Consider. 2000, The ASEAN Centre:

62.Software Park Thailand Software Industry Promotion and Development Strategy, Software Park Thailand, (2002).

63.Software Park Thailand, Introduction of Software Park. 2003, 
64.Sooksiriserikul, S. Potential and capacity of Thailand in IT industry competitiveness, Institute of Human Resource, Thammasat University, (2000).

65.Strategis, Market Assessment. 2003, Industry Canada:

66.Talero, E., and Gaudette, P. Harnessing Information for Development: A Proposal for a World Bank Group Strategy, World Bank, (1996).

67.Tallon, P.P., and Kraemer, K.L. Information technology and economic development: Ireland's coming of age with lessons for developing countries, CRITO, (1999).

68.Tan, F.B. The responsiveness of information technology to business strategy formulation: An empirical study. Journal of Information Technology, 10, (1995), 171-178.

69.Thajchayapong, P.; Reinermann, H.; Goodman, S.E.; and Pipe, R. Social Equity and Properity: Thailand Information Technology Policy into the 21st Century. The Information Society, 13, (1997), 265-286.

70.The Economist Intelligence Unit, E-Commerce growth in Thailand. 2001, The Economist Intelligence Unit:

71.Thuvasethakul, C., and Koanantakool, T. National ICT Policy in Thailand, in Proceedings of Africa-Asia Workshop, Malaysia, 2002.

72.Tiralap, A. The Electronics industry in Thailand, Thailand Development Research Institute, (1997).

73.Trade partners UK, IT \& Electronics Market in Thailand. 2000, UK government:

74.UNESCO UNESCO Statistical Yearbook. USA: UNESCO Publishing \& Bernan Press, 1999.

75.Watson, R., and Myers, M.D. IT Industry Success in Small Countries: The Cases of Finland and New Zealand. Journal of Global Information Management, 9, 2, (2001), 1-14.

76.World Bank, Thailand at a glance. 2002a,

77.World Bank World Development indicators. Washington, D.C.: The World Bank, 2002b.

78.WorldBank, World Development Indicators database. 2002,

79.Xavier, P. Bridging the 'digital divide': issues and policies in OECD countries, DSTI/ICCP(2001)9/FINAL, Organisation for Economic Co-operation and Development, (2001).

80.Yamada, N. IT Movement in Southeast Asia: Case of Singapore, Malaysia and Thailand, in Masatsugu Tsuji, ed., The 'IT' revolution and developing Countries: Late-comer advantage?, Institute of developing economies, 2001.

81.Yin, R.K. Case Study Research Design and Methods. California: SAGE Publications Ltd, 1984. 